\title{
Homograft aortic valve replacement in aortic incompetence and stenosis
}

\author{
B. G . B A R R A T T - B O Y E S \\ From the Cardio-thoracic Surgical Unit, Green Lane Hospital, Auckland, New Zealand
}

The surgery of aortic incompetence and calcific aortic stenosis has made disappointing progress, chiefly because of the need for partial or total valve replacement in many of these patients and the technical problems inherent in designing an artificial valve. In rheumatic aortic incompetence it is now fairly clear that total replacement of the valve is almost always required (McGoon, Mankin, and Kirklin, 1963), and in calcific aortic stenosis the lesion is by no means always adequately relieved by decalcifying the cusps, so that partial or total valve replacement is necessary in a proportion of these cases also.

Dissatisfaction with the available plastic aortic valve prostheses led to a review of the experimental and clinical experience with homograft aortic valves. The experimental evidence (Murray, 1956 ; Lam, Aram, and Munnell, 1952 ; Brewin, 1956 ; Beall, Morris, Cooley, and De Bakey, 1961), while a little conflicting, suggests that with the host valve rendered incompetent a homograft valve will function in the dog. Clinical experience from Toronto (Murray, 1956; Kerwin, Lenkei, and Wilson, 1962), where homograft aortic valves have been inserted in the descending thoracic aorta in patients with severe aortic incompetence, shows that these valves will function normally for up to six years. The evidence seemed sufficient to justify attempts to insert homograft valves in a subcoronary position in anticipation that they would function better and for longer periods than plastic prostheses.

The technique used for inserting the valve was based on experience gained in approximately 100 open operations on the aortic valve and was first used in August 1962 before receiving the report of a similar procedure performed by Ross (1962) at about the same time. The technique has proved very satisfactory and the valves have all continued to function well. Indeed the experience presented here, including necropsy examination of two valves three and a half and four and a half months after insertion, is most encouraging and suggests that homograft aortic valves are worthy of serious consideration for aortic valve replacement.

\section{MATERIAL}

During the 16 months from August 1962 to November 1963 inclusive, the aortic valve has been completely excised and replaced by a homograft aortic valve in 21 patients with aortic incompetence, 17 with calcific aortic stenosis, and six with multivalvular disease. Clinical data obtained before and after operation in these 44 patients and various operative findings are listed in the Table. In this same period one further patient with aortic incompetence underwent operation, and it was intended to replace the valve with a homograft valve. Death occurred, however, immediately bypass was started from retroperitoneal rupture of an aortic dissection which began at the site of cannulation of the external iliac artery and ended at the point of rupture. The aortic wall showed extensive medionecrosis at necropsy. Although this was a 'perfusion' death, it does not reflect directly on homograft valve replacement and will not be considered further.

The ages varied from 14 to 66 years, and 20 patients were over the age of 50 . Symptoms have been divided into four grades of severity: grade 4 if there was a history of congestive heart failure, paroxysmal nocturnal dyspnoea, orthopnoea or angina decubitus ; grade 3 if there was angina of effort or syncope in addition to effort dyspnoea ; and grade 2 if there was moderate effort dyspnoea only. On this basis 28 of the 44 patients had grade 4 symptoms, 11 grade 3, and five grade 2 . The electrocardiogram showed a complete left bundle branch block in cases 22 and 31 and a complete right bundle branch block in case 21 . Left ventricular surface leads and their equivalents showed inverted $\mathrm{T}$ waves with or without ST depression, indicating severe left ventricular hypertrophy in all but three of the remaining patients, and in these (cases 16 . 19 . and 35 ) the changes were moderate with $T$ waves of low voltage.

PREVIOUS SURGERY Four patients had had previous heart-lung bypass surgery, three for calcific aortic stenosis (cases 12,17, and 22) and one (case 15) for ventricular septal defect with severe aortic incompetence. In case 12 the surgery was undertaken else- 
T A B LE

\begin{tabular}{|c|c|c|c|c|c|c|c|c|c|c|c|}
\hline \multirow[b]{2}{*}{$\begin{array}{l}\text { Case } \\
\text { No. }\end{array}$} & \multirow[b]{2}{*}{$\begin{array}{l}\text { Age/Sex/ } \\
\text { Operation }\end{array}$} & \multirow{2}{*}{$\begin{array}{c}\text { Grade } \\
\text { of } \\
\text { Symp- } \\
\text { toms }\end{array}$} & \multirow[b]{2}{*}{$\begin{array}{c}\text { B.P. } \\
(\mathrm{mm} \cdot \mathrm{Hg})\end{array}$} & \multicolumn{3}{|c|}{ Perfusion Data } & \multirow{2}{*}{$\begin{array}{c}\text { Gradient } \\
\text { Across } \\
\text { Homo- } \\
\text { graft } \\
\text { valve } \\
\text { (mm.Hg) }\end{array}$} & \multirow[b]{2}{*}{$\begin{array}{l}\text { Post-operative } \\
\text { Complications }\end{array}$} & \multicolumn{3}{|c|}{ Follow-up (December 1963) } \\
\hline & & & & $\begin{array}{l}\text { By-pass } \\
\text { (min.) }\end{array}$ & $\begin{array}{c}\text { Perfusion } \\
\text { (min.) }\end{array}$ & $\begin{array}{c}\text { nysis } \\
\text { (mg. \%) }\end{array}$ & & & $\begin{array}{c}\text { B.P. } \\
\text { (mm. } \mathrm{Hg})\end{array}$ & Murmur ${ }^{1}$ & Status \\
\hline 1 & & 4 & $140 / 35-0$ & 101 & ${ }_{88}^{\text {Aortic }}$ & ic Incompete & $\left.\right|_{0} ^{\text {tence }} 0$ & Nil & $105 / 70$ & M.S.M. 0-1 & Good \\
\hline 2 & $\begin{array}{c}23.8 .62 \\
21 \mathrm{M} \\
9.10 .62\end{array}$ & 4 & $135 / 30-0$ & 114 & 93 & 52 & $\mathbf{0}$ & Nil & $115 ; 90$ & $\begin{array}{l}\text { E.D.M. } 0-1 \\
\text { M.S.M. } 1-2\end{array}$ & $\begin{array}{l}\text { Poor } \\
\text { (Cardio- } \\
\text { myopathy) }\end{array}$ \\
\hline 3 & $\begin{array}{l}54 \mathrm{M} \\
6.11 .62\end{array}$ & 4 & $180 / 40$ & 108 & 83 & 144 & 0 & Nil & $165 ; 80$ & M.S.M. 1 & Good \\
\hline 4 & $\begin{array}{c}0.1 .02 \\
36.12 \\
18.12 .62\end{array}$ & 3 & $170 / 40-0$ & 143 & 101 & 146 & - & Nil & 15090 & $\begin{array}{l}\text { M.S.M. } 1-2 \\
\text { E.D.M. } 1-2\end{array}$ & Good \\
\hline 5 & $\begin{array}{l}32 \mathrm{~F} \\
15.1 .63\end{array}$ & 3 & $160 / 20-0$ & 112 & 88 & 88 & 8 & Bleeding, Died & & & \\
\hline 6 & $\begin{array}{c}27 \mathrm{M} \\
29.1 .63\end{array}$ & 2 & 17060 & 117 & 82 & 40 & 3 & $\begin{array}{l}\text { Positive blood } \\
\text { culture }\end{array}$ & $135 / 85$ & $\begin{array}{l}\text { M.S.M. 1-2 } \\
\text { E.D.M. } 1-2\end{array}$ & Good \\
\hline 7 & $\begin{array}{r}62.1 .03 \\
28.2 .63\end{array}$ & 4 & $140 / 50$ & 100 & 78 & 39 & 4 & Nil & $145 / 85$ & $\begin{array}{l}\text { E. M.M. } 1-2 \\
\text { E.D.M. } 1-2\end{array}$ & $\underset{\text { Died }}{\text { Dune } 1963}$ \\
\hline 8 & $\begin{array}{r}45 \mathrm{M} \\
14.3 .63\end{array}$ & 3 & $180 / 40-0$ & 105 & 84 & 56 & 0 & Nil & 140.85 & M.S.M. 0-1 & $\begin{array}{l}\text { Died } \\
\text { (July } 1963\end{array}$ \\
\hline 9 & $\begin{array}{l}55 \mathrm{M} \\
18.4 .63\end{array}$ & 4 & $200 / 60$ & 116 & 81 & 29 & - & Nil & 140,85 & $\begin{array}{l}\text { M.S.M. 1-2 } \\
\text { E.D.M. 0-1 }\end{array}$ & Good \\
\hline 10 & $\begin{array}{l}52 . \mathrm{M} \\
2.5 .63\end{array}$ & 4 & $165 / 35$ & 179 & 153 & 59 & 10 & Nil & $130 ; 70$ & M.S.M. $1-2$ & Good \\
\hline 11 & $\begin{array}{l}23 \mathrm{M} \\
8.5 .63\end{array}$ & 2 & $165 / 35-0$ & 104 & 82 & 28 & 0 & Nil & $160 / 90$ & $\begin{array}{l}\text { M.S.M. 1 } \\
\text { P.S.M. 1-2 }\end{array}$ & Good \\
\hline 12 & $\begin{array}{c}60 \mathrm{~F} \\
12.6 .63\end{array}$ & 4 & 17040 & 95 & 77 & 46 & 3 & Nil & $130 / 70$ & M.S.M. 1-2 & Good \\
\hline 13 & $\begin{array}{l}17 \mathrm{~F} \\
27.6 .63\end{array}$ & 4 & 1500 & 105 & 85 & 47 & 0 & Nil & 13080 & $\begin{array}{l}\text { M.S.M. 1-2 } \\
\text { E.D.M. } 1-2\end{array}$ & Good \\
\hline 14 & $\begin{array}{l}27 \mathrm{M} \\
3.7 .63\end{array}$ & 4 & 13030 & 127 & 96 & 24 & 14 & $\begin{array}{l}\text { Post-perfusion } \\
\text { syndrome }\end{array}$ & 11080 & $\begin{array}{l}\text { M.S.M. } 2 \\
\text { E.D.M. 1-2 }\end{array}$ & Good \\
\hline 15 & $\begin{array}{l}16 \mathrm{M} \\
31.7 .63\end{array}$ & 4 & 1450 & 101 & 67 & 30 & - & Nil & 14075 & $\begin{array}{l}\text { M.S.M. } 2 \\
\text { E.D.M. } 2\end{array}$ & Good \\
\hline 16 & $\begin{array}{l}23 \mathrm{M} \\
17.10 .63\end{array}$ & 2 & 14055 & 150 & 121 & 57 & - & Nil & 13580 & M.S.M. 1-2 & Good \\
\hline 17 & $\begin{array}{r}60 \mathrm{M} \\
29.10 .63\end{array}$ & 4 & $170 / 60$ & 96 & 78 & 30 & - & Nil & $150 / 80$ & $\begin{array}{l}\text { M.S.M. } 1 \\
\text { E.D.M. 1-2 }\end{array}$ & Good \\
\hline 18 & $\begin{array}{l}63 \mathrm{M} \\
6.11 .63\end{array}$ & 4 & $130 / 40$ & 128 & 103 & 15 & - & Nil & $130 / 85$ & $\begin{array}{l}\text { M.S.M. } 1-2 \\
\text { E.D.M. } 0-1\end{array}$ & Good \\
\hline 19 & $\begin{array}{l}18 \mathrm{M} \\
7.11 .63\end{array}$ & 2 & 1400 & 91 & 71 & 47 & - & Nil & 13085 & M.S.M. 1 & Good \\
\hline 20 & $\begin{array}{r}41 \mathrm{M} \\
12.11 .63\end{array}$ & 4 & $205 / 50-0 \mid$ & 132 & 102 & 150 & - & $\begin{array}{l}\text { Arrhythmia } \\
\text { cardiac arrest }\end{array}$ & $160 / 100$ & $\begin{array}{l}\text { M.S.M. 1-2 } \\
\text { E.D.M. } 1-2\end{array}$ & Good \\
\hline 21 & $\begin{array}{l}48 \mathrm{M} \\
21.11 .63\end{array}$ & 4 & $220 / 50-0$ & 117 & 90 & 36 & - & $\mathrm{Nil}$ & 14099 & M.S.M. 1-2 & Good \\
\hline 22 & $\begin{array}{l}47 \mathrm{M} \\
13.12 .62\end{array}$ & 4 & 11080 & 132 & $\begin{array}{c}\text { Calcific } \\
103\end{array}$ & $\begin{array}{c}\text { Aortic } \\
\quad 304\end{array}$ & $\begin{array}{c}\text { Stenosis } \\
4\end{array}$ & Nil & $125 / 80$ & $\cdot 1-2$ & Good \\
\hline 23 & $\begin{array}{c}53 \mathrm{M} \\
27.2 .63\end{array}$ & 3 & $110 / 80$ & 133 & 113 & 30 & 36 & Pulmonary embolus & $135 / 80$ & M.S.M. 1-2 & Good \\
\hline 24 & $\begin{array}{r}59 \mathrm{M} \\
11.6 .63\end{array}$ & 4 & $110 / 85$ & 143 & 106 & 40 & - & Nil & $110 / 70$ & M.S.M. 1 & Good \\
\hline 25 & $\begin{array}{l}54 \mathrm{M} \\
9.7 .63\end{array}$ & 3 & 10570 & 121 & 94 & 15 & 8 & Pulmonary embolus & $110 / 70$ & M.S.M. 1 & Good \\
\hline 26 & $\begin{array}{r}45 \mathrm{M} \\
10.7 .63\end{array}$ & 4 & $110: 50$ & 125 & 95 & 33 & - & Nil & $130 / 85$ & $\begin{array}{l}\text { M.S.M. 1-2 } \\
\text { E.D.M. 1-2 }\end{array}$ & Good \\
\hline 27 & $\begin{array}{r}51 \mathrm{M} \\
18.7 .63\end{array}$ & 3 & 120775 & 128 & 104 & 43 & 6 & $\begin{array}{l}\text { Dissection left } \\
\text { coronary } \mathrm{Di}\end{array}$ & & E.D.M. 1-2 & \\
\hline 28 & $\begin{array}{l}54 \mathrm{M} \\
23.7 .63\end{array}$ & 3 & $120 / 75$ & 121 & 99 & 27 & 0 & Pulmonary embolus & $130 ; 80$ & M.S.M. 0-1 & Good \\
\hline 29 & $\begin{array}{l}50 \mathrm{~F} \\
6.8 .63\end{array}$ & 3 & $120 / 80$ & 130 & 95 & 56 & 0 & $\begin{array}{l}\text { Heart block } \\
\text { (temporary) }\end{array}$ & 130.80 & M.S.M. 1-2 & Good \\
\hline 30 & $\begin{array}{l}52 . \mathrm{M} \\
8.8 .63\end{array}$ & 4 & $110 / 50$ & 109 & 72 & 22 & 0 & Nil & $115 / 70$ & M.S.M. 1-2 & Good \\
\hline 31 & $\begin{array}{l}56 . \mathrm{M} \\
15.8 .63\end{array}$ & 3 & $135 / 80$ & 134 & 107 & 69 & 0 & $\begin{array}{l}\text { Post-perfusion } \\
\text { syndrome }\end{array}$ & $130 / 70$ & $\begin{array}{l}\text { M.S.M. 1-2 } \\
\text { E.D.M. 1-2 }\end{array}$ & Good \\
\hline 32 & $\begin{array}{r}50 \mathrm{~F} \\
22.8 .63\end{array}$ & 3 & $125 / 85$ & 111 & 78 & 27 & 0 & Nil & $140 / 80$ & M.S.M. 1-2 & Good \\
\hline 33 & $\begin{array}{l}57 \mathrm{M} \\
4.9 .63\end{array}$ & 4 & $115 / 75$ & 117 & 81 & 19 & 0 & $\begin{array}{c}\text { Post-cardiotomy } \\
\text { syndrome }\end{array}$ & $130 / 85$ & $\begin{array}{l}\text { M.S.M. 1-2 } \\
\text { E.D.M. } 0-1\end{array}$ & Good \\
\hline 34 & $\begin{array}{l}52 \mathrm{M} \\
16.10 .63\end{array}$ & 2 & 14090 & 111 & 83 & 41 & - & $\mathrm{Nil}$ & $135 / 85$ & M.S.M. 1 & Good \\
\hline 35 & $\begin{array}{l}36 \mathrm{M} \\
30.10 .63\end{array}$ & 3 & $110 / 85$ & 148 & 123 & 56 & 0 & Nil & $125 / 70$ & M.S.M. 1 & Good \\
\hline 36 & $\begin{array}{l}6.10 \mathrm{M} \\
31.10 .63\end{array}$ & 4 & $160 / 115$ & 128 & 83 & 45 & - & $\begin{array}{l}\text { Heart block } \\
\text { (temporary) }\end{array}$ & $130 / 80$ & M.S.M. 1 & Good \\
\hline 37 & $59 \mathrm{M}$ & 4 & $120 / 65$ & 137 & 80 & 20 & - & $\mathrm{Nil}$ & $130 / 75$ & M.S.M. 1 & Good \\
\hline 38 & $\begin{array}{r}59 \mathrm{M} \\
14.11 .63\end{array}$ & 4 & $140 / 70$ & 105 & 81 & 65 & - & Nil & 115.70 & M.S.M. 1 & Good \\
\hline
\end{tabular}


TABLE-(continued)

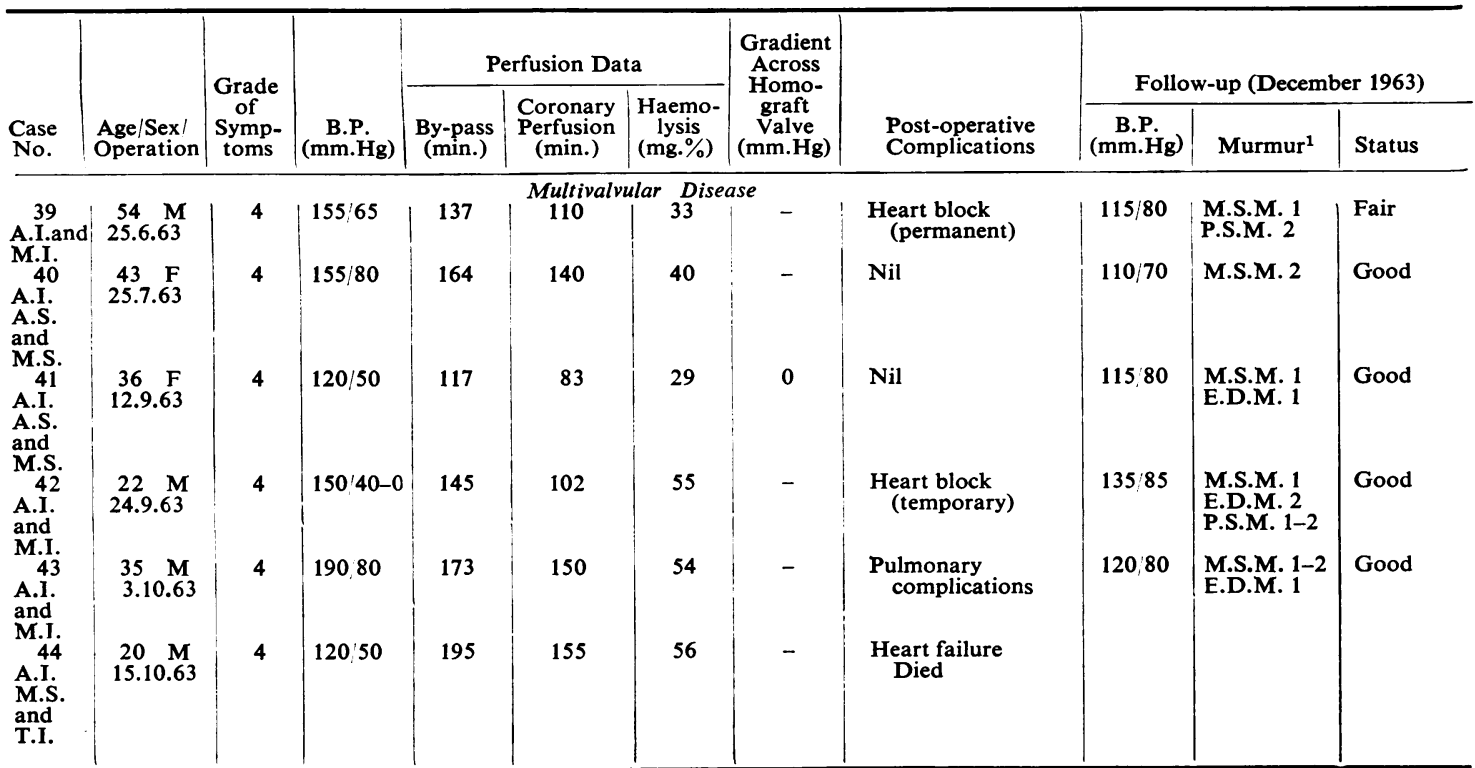

1 Murmurs graded 1 to 4. M.S.M. = mid-systolic (aortic) ; E.D.M. = early diastolic (aortic) ; P.S.M. = pan stystolic (mitral). A.I. = aortic incompetence ; M.I. = mitral incompetence ; T.I. = tricuspid incompetence ; A.S. = aortic stenosis ; M.S. = mitral stenosis.

where in October 1958, when one cusp of a bicuspid valve was replaced with an artificial leaflet and the other leaflet partially decalcified. This operation was followed by renal shutdown which required dialysis twice before function returned, but the patient was moderately improved for a year or so, when angina returned: later congestive heart failure appeared. Aortic incompetence was then evident, although pressures recorded at the second operation showed a residual gradient of $60 \mathrm{~mm}$. $\mathrm{Hg}$ across the valve. The artificial leaflet had shrivelled and its remnant was completely calcified. Pre-operatively renal function showed a reduced creatinine clearance of $63 \mathrm{ml} . / \mathrm{min}$. and a raised blood urea of $62 \mathrm{mg} . / 100 \mathrm{ml}$. This patient tolerated the second perfusion and homograft valve replacement extremely well without evidence of further renal damage.

In case 17 the first operation was performed at Green Lane Hospital in February 1963. Two of the calcified cusps disintegrated and were replaced by teflon leaflets (Bahnson, Spencer, Busse and Davis, 1960), with a good immediate result but with the appearance within three weeks of aortic incompetence which gradually became very severe. At the second operation the incompetence was found to be due to tearing of one of the teflon cusps near its attachment to the aorta.

In case 22 , surgery had been undertaken at Green Lane Hospital in 1961 when myocardial cooling without continuous coronary perfusion was in use. Decalcification of the valve was attempted but in the time available the cusps were not fully mobilized. Symptoms recurred within eight months and progressed to effort dizziness and paroxysmal nocturnal dyspnoea, and physical signs indicated a return of severe aortic stenosis.

In case 15 the initial operation was in May 1963, at which time the ventricular septal defect was closed and the prolapsing right aortic cusp was replaced with a teflon leaflet with an excellent immediate result. Aortic incompetence soon re-appeared, however, and rapidly progressed until the boy was in uncontrollable heart failure. In addition, a continuous fever was present and splinter haemorrhages kept appearing in the nail beds, indicating infection, although this was never proven. At the second operation the teflon leaflet still appeared to be functioning well, and the incompetence was due to partial detachment of the non-coronary cusp where it met the teflon leaflet.

ASSOCIATED LESIONS Clinical assessment suggested that two patients in the aortic incompetence group (cases 11 and 14) also had mitral incompetence that was too mild to require surgical attention. This was borne out by pressure measurements taken at operation and by the post-operative course, because after complete correction of the aortic leak the mitral incompetence became inconspicuous.

Two patients had large intrapericardial ascending arch aneurysms in association with aortic incompetence (cases 10 and 18). In both, in addition to inserting a homograft aortic valve, the aneurysm was 
completely excised and the aorta reconstituted by direct end-to-end anastomosis just above the new valve. In case 10 the aneurysm was syphilitic and communicated with the right pulmonary artery. This acquired aorto-pulmonary window was not suspected for the murmur was not continuous, presumably because the valvular incompetence was severe enough to lower aortic diastolic pressure and prevent a large left to right shunt throughout diastole. In case 18 the aneurysm was probably the result of a localized long-standing aortic dissection.

One patient (case 30) was thought to have a bronchogenic carcinoma producing marked stenosis of the right upper lobe bronchus and a right hilar mass. Bronchoscopic biopsy and sputum cytology were repeatedly negative, and, as the aortic stenosis was severe, the lung lesion was treated by radiotherapy alone, using the linear accelerator. There was considerable clearing of the hilar shadows and improvement in the bronchoscopic appearances. His cardiac status continued to deteriorate until frank heart failure appeared, and at this stage-10 months after completion of radiotherapy-aortic valve surgery was performed without complications. There has been no recurrence to date of pulmonary disease.

Six patients had pre-operative renal damage. This was most marked in case 6 , as already detailed, but the creatinine clearance was reduced to between 60 and $70 \mathrm{ml} . / \mathrm{min}$. in cases 18,36 , and 37 and to approximately $80 \mathrm{ml} . / \mathrm{min}$. in cases 3 and 41 , and the blood urea was also at the upper limits of normal in these five patients.

The six patients in the multivalvular disease group all had aortic incompetence and mitral valve disease with advanced cardiac decompensation. In cases 40 and 41 there was some degree of aortic stenosis but with enough incompetence to make valve replacement mandatory. Mitral incompetence was moderate in case 39 and severe in cases 42 and 43 , and in two of these patients it was the result of bacterial endocarditis with chordal rupture. Mitral stenosis was severe in cases 40,41 , and 44 and was associated with severe organic tricuspid incompetence in case 44 .

CATHETERIZATION In eight patients preliminary cardiac catheterization was undertaken for a variety of reasons: in cases 16 and 17 to exclude associated mitral stenosis; in cases 3,27 , and 35 to confirm that the aortic lesion was severe; in three of the patients with multivalvular disease (cases 40,41 , and 44) in an attempt to quantitate the severity of each lesion. Coronary angiography was not done as associated coronary artery disease was not considered a contraindication to operation for severe aortic valve disease.

\section{TECHNIQUE}

Homograft aortic valves were removed within 15 hours of death. The age of the donors was limited at first to less than 45 years, but some more recent valves, for use in older patients, were taken from subjects up to the age of 55 years. A full sterile tech-음 nique was used in the majority of cases, but latterly듬 a number of valves have been taken by the pathologist $\overline{\bar{\omega}}$ unsterile and immediately sterilized using beta- $\vec{\Phi}$ propiolactone (Rains, Crawford, Sharpe, Shrewsbury, and Barson, 1956). The valves were then placed in w nutrient medium similar to that described by Gross, $\overrightarrow{0}$ Bill, and Peirce (1949), to which penicillin and strepto-? mycin were added, and stored at $4^{\circ} \mathrm{C}$. for up to a $\vec{\omega}$ week before freeze-drying. They were cultured justo before being placed in the medium and again on $F$ removal before freeze-drying: if positive they were ${ }^{\times}$ not used. After freeze-drying, the outside of the sealed $\overrightarrow{0}$ glass vacuum tube was sterilized in an ethylene oxideiv gas chamber at body temperature. Freeze-dried valves $\vec{\omega}$ were reconstituted by placing them in distilled water for 30 minutes and then in isotonic saline.

The valves were inserted with the aid of a heart-lungmachine of either Melrose or Kay Cross design with $\bar{Z}$ modifications to the venous side of the oxygenator circuit (Barratt-Boyes and Yarrow, 1961). The machine was primed with a mixture of two parts of $-\overrightarrow{0}$ heparinized blood (drawn on the morning of operation) to one part of $5 \%$ glucose containing $5 \mathrm{~g}$. of serum albumin per $100 \mathrm{ml}$. The mediastinum was opened through a vertical sternal-splitting incisions avoiding entry into either pleural cavity. The arteriae cannula was inserted into the external iliac artery both to ensure as low an arterial line pressure as possible and to avoid any possibility of contaminating the thoracic field from a groin incision. A single righ $\vec{\sigma}$ atrial cannula was used, except in cases 10 and 18,3 where both cavae were taped and two caval lines inserted: this was because previous experience had shown that a single right atrial line is dangerous in ascending aortic arch aneurysm where there is a pos sibility of holing the pulmonary artery. In case 10 it was fortunate that both caval tapes were in position ${ }^{x}$ as there was an unsuspected aorto-pulmonary communication.

The patients were cooled to a nasopharyngeap temperature of $30^{\circ} \mathrm{C}$, and perfusion flow was fixed at $21 . / \mathrm{m}^{2} / \mathrm{min}$. during the cooling phase to allow the heart to contribute to the circulation in the expectation that body cooling would be more unifornis and in patients with severe aortic incompetence, to prevent overdistension of the left ventricle froms excessive retrograde aortic flow during the cooling phase. The aorta was cross-clamped in cases with incompetence immediately there was any suggestion of overdistension of the left ventricle, and in others at $30^{\circ}$ C.; it was then opened transversely abou $b$ $5 \mathrm{~mm}$. above the origin of the right coronary arter around at least three-quarters of its circumference Just before cross-clamping the aorta, a metal-tipped suction line was inserted through the apex of the lef 5 ventricle to empty the left heart. Suction on this line्षे was maintained by a Sigmamotor pump, and a second? open-heart line with a separate pump was also avail $\mathbb{\complement}$ able. Because of the importance in long perfusions of preventing significant haemolysis, the open-hearf 
pumps were repeatedly adjusted to avoid excessive air in the lines. Moreover the perfusion flow was maintained at $21 . / \mathrm{m}^{2} / \mathrm{min}$. until towards the end of the procedure when rewarming had been started and the nasopharyngeal temperature had reached $32^{\circ} \mathrm{C}$., at which time flows were increased to $2.41 . / \mathrm{m}^{2} / \mathrm{min}$. In addition to keeping flows fixed at $21 . / \mathrm{m}^{2} / \mathrm{min}$., as soon as the aorta was cross-clamped blood was taken from the patient into the machine until right atrial pressures were negative. This manœuvre helped to decompress the heart and lungs, to lessen open-heart return, and thus to improve operating conditions. When a single right atrial cannula is used and flows are fixed at $21 . / \mathrm{m}^{2} / \mathrm{min}$., it is of course imperative to have a low venous pressure if the heart is still beating, otherwise some of the right atrial return will be pumped through the lungs and will appear in the left heart field; in about half the cases the heart continued to beat throughout the procedure. The patient's arterial pressure was monitored continuously, and in the few cases in which mean arterial pressure fell below $70 \mathrm{~mm}$. Hg during perfusion, blood was returned to the patient and flows increased. Otherwise blood was not returned until the rewarming phase.

As soon as the left heart was emptied of blood, the left and right coronary arteries were cannulated. The blood for coronary perfusion was taken by a separate line from the arterial end of the oxygenator and was not separately filtered or cooled. The myocardium was thus maintained at a temperature of approximately $30^{\circ}$ C. Plastic coronary artery lines were used with metal tips fitted with self-inflating rubber cuffs of Mayo Clinic design (Fig. 1). Care was taken to avoid advancing the left coronary cannula tip too far and so perfusing only one major branch of this vessel. These cannulae proved very satisfactory as blood rarely leaked around them. During subsequent surgical manipulations, however, they were liable to displacement unless further secured, and this was satisfactorily achieved by a single stitch through the aortic wall close to each coronary orifice (Fig. 2). The two ends of the stitch were passed through a length of fine rubber tubing and, after snuggling the end of this tubing down on to the outer aortic wall, the plastic tubing of the coronary line was held firmly against the inner aortic wall. The two stitches, one for each coronary line, were left in place until aortic closure was almost completed. Both coronary arteries were separately perfused with a Sigmamotor pump at a flow of 150 to $200 \mathrm{ml} . / \mathrm{min}$., with monitoring of line pressures just beyond the pump heads. This pressure averaged 150 to $200 \mathrm{~mm}$. $\mathrm{Hg}$, and the coronary tips were adjusted whenever necessary to prevent a rise above $300 \mathrm{~mm}$. $\mathrm{Hg}$. In eight patients the right coronary artery was not perfused. In case 1 , aged 14, the orifice was too small ; in cases 12 and 29 it was absent; in case 21 it was pin hole in size due to extensive fibrous thickening and calcification within the aortic wall from syphilitic aortitis. In the other four patients (cases 17, 18, 36, and 37), with an average age of 62 years, it was possible to cannulate the right coronary orifice accurately but not to perfuse the artery as line pressures immediately rose precipitately. It is almost certain that these arteries were blocked close to their origins. In these eight patients flow through the left coronary cannula was increased and blood temperature was dropped to approximately $27^{\circ} \mathrm{C}$.

Placement of the coronary cannulae in the way described took only a few minutes, and further attention to them was seldom required. The aortic valve was then excised. When fibrous, a peripheral cusp remnant was left: if extensively calcified, the calcium was nibbled away carefully from the aortic wall and ventricular outflow tract with complete removal of the cusps. The homograft aortic valve was then sutured
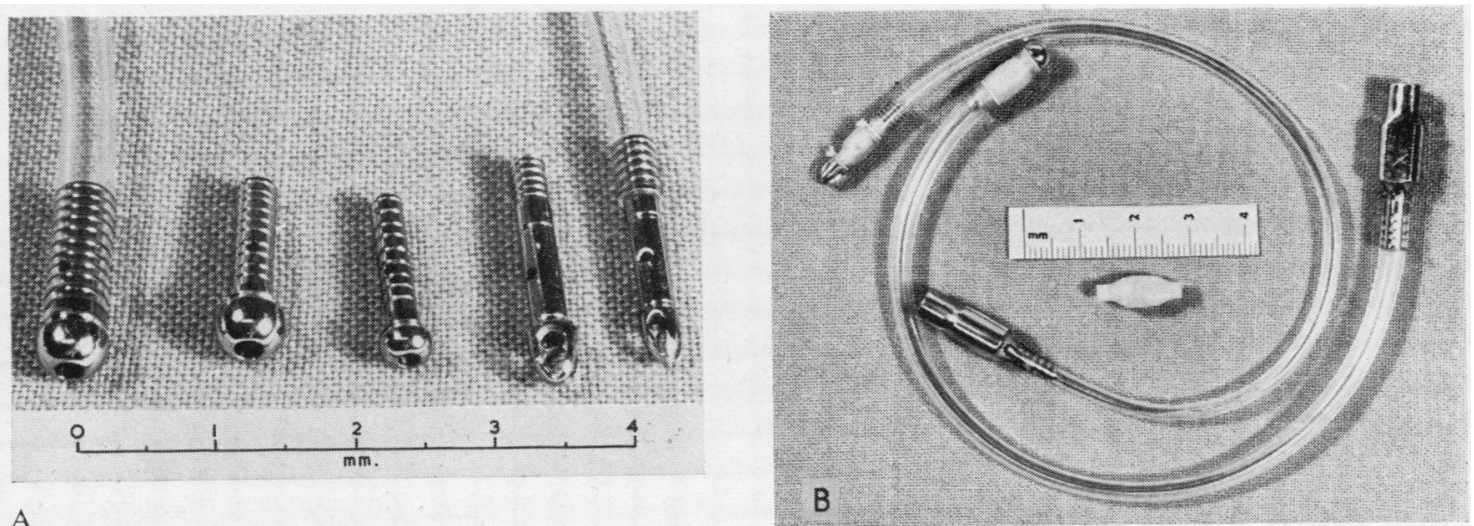

A

FIG. 1. (A) Metal coronary artery perfusion tips. The left coronary tips are made in three sizes with a mushroomshaped end: the right in two sizes with a basket tip. (B) Large left and small right corcnary artery perfusion cannulae. The rubber cuffs, one of which is shown separately in the centre of the photograph, are tied over the metal tips and are automatically inflated, once the tip lies in the coronary orifice, when blood passes through the side hole beneath the cuff. 

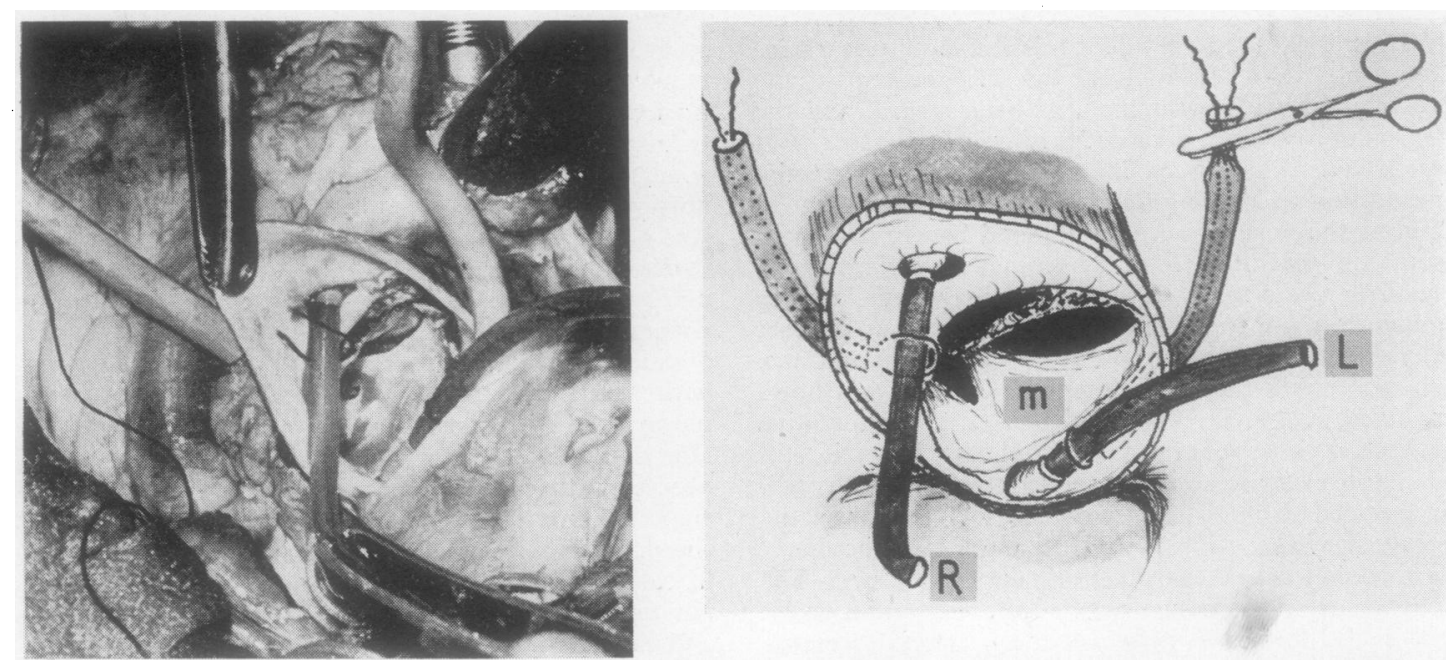

FIG. 2. Coronary artery cannulae in position at operation. The transverse aortic incision is shown. The retaining suture around the right coronary cannula is in position anteriorly, but the rubber sling through which the ends of ${ }^{+}$ the suture have been passed is not yet tightened down onto the outside of the aorta. The left coronary cannula is also positioned with its retaining suture snugged tight. The aortic valve has been excised, giving a clear view of the anterior mitral leaflet $(\mathrm{m})$.
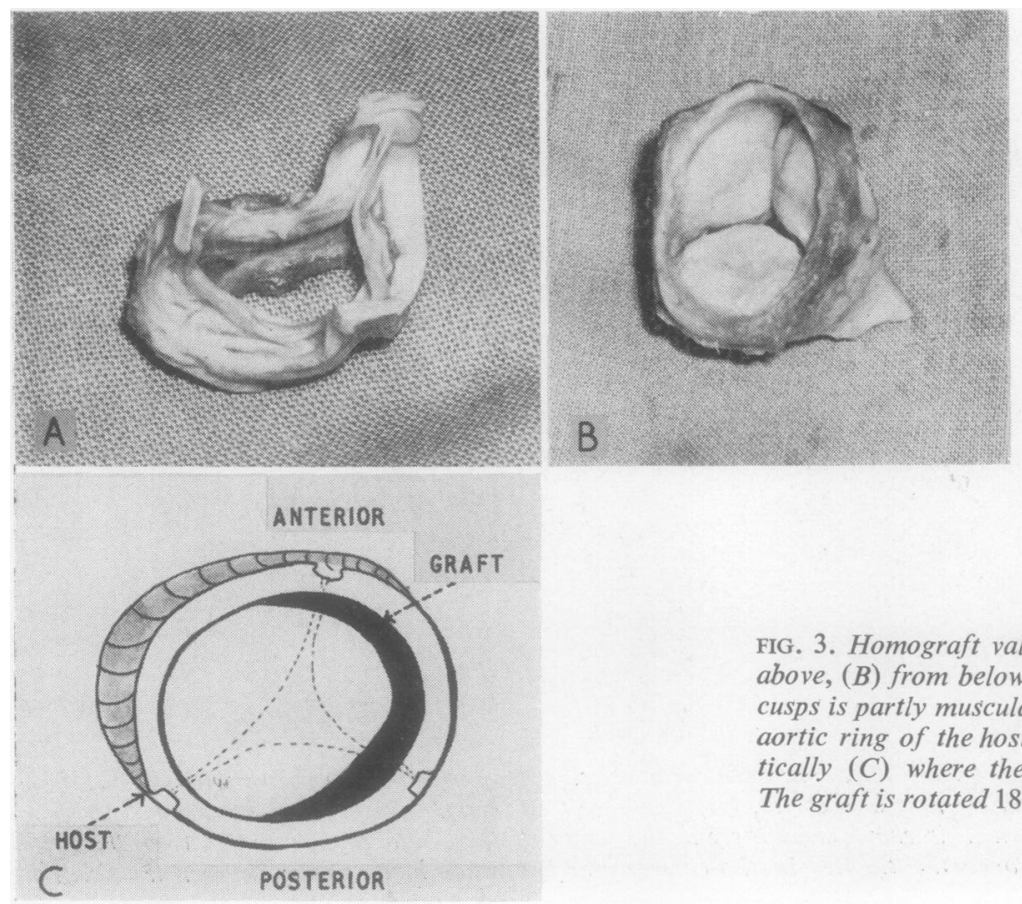

FIG. 3. Homograft valve prepared for insertion (A) froms above, $(B)$ from below. Note that the aortic ring below the cusps is partly muscular. The position of this muscle in the aortic ring of the host and the graft is shown diagramma $-\vec{D}$ tically $(C)$ where the thicker muscular tissue is shaded The graft is rotated $180^{\circ}$ to avoid sewing muscle to muscle 


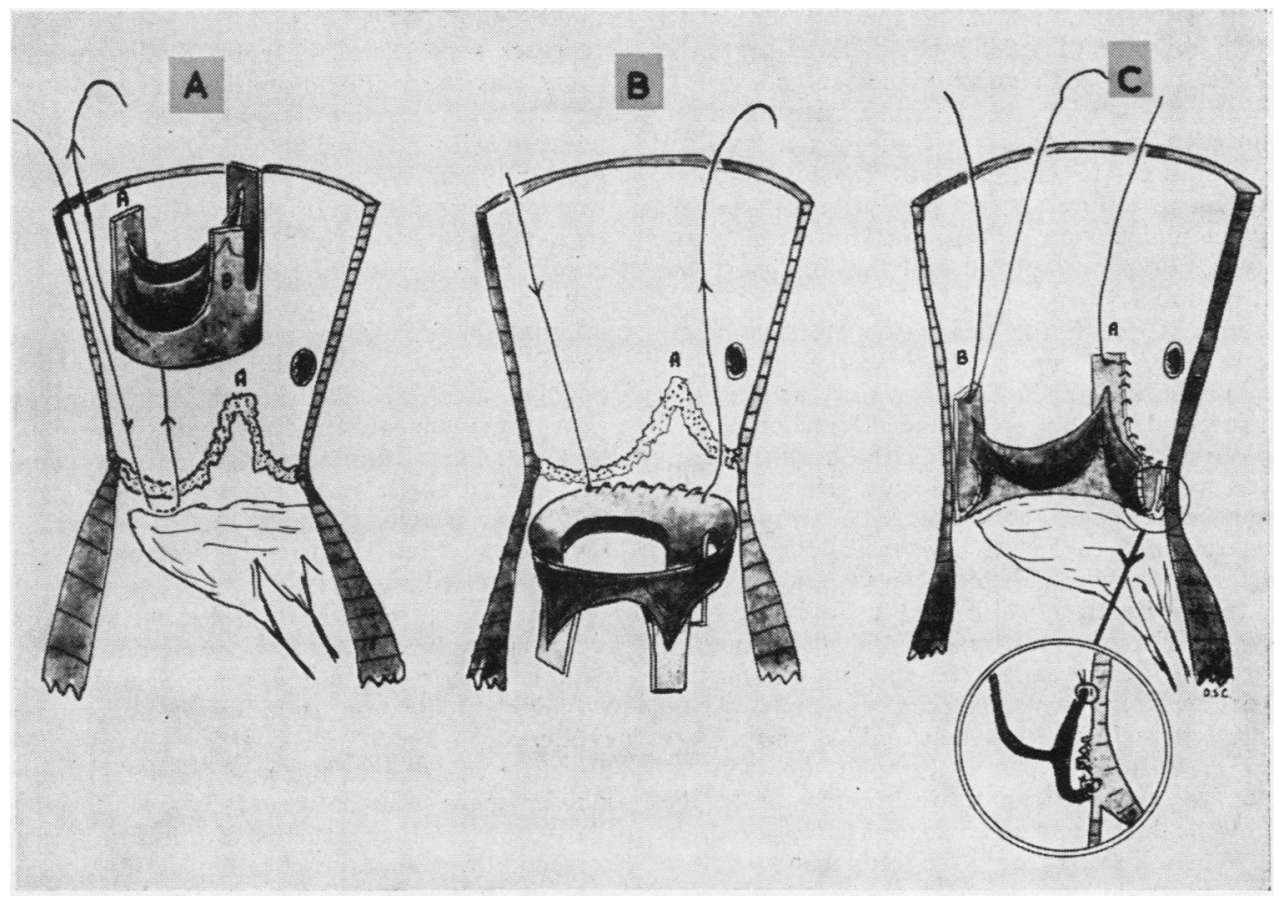

FIG. 4. Technique of insertion of valve. (A) The first stay suture is in place; (B) the valve is inverted down into the left ventricle and the three stay sutures are tied. The lower suture line is begun; $(C)$ the valve is in its final position and the three highest points of the graft have been attached with the upper suture line partly completed. The insert shows how the lower suture line becomes buried when the valve is pulled upwards.

into position below the coronary ostia. The aortic wall was trimmed from the homograft by cutting away the aortic sinuses above (Fig. 3A), leaving the aortic ring intact just below the cusps (Fig. 3B). Two continuous suture lines were used, one through the aortic ring below the cusps and the secend following the line of the aortic remnant above each cusp. Unfortunately, the aortic ring below the cusps, while fibrous posteriorly, is largely friable muscular tissue anteriorly: for this reason the homograft valve was rotated through $180^{\circ}$ (Fig. 3C) so that the more difficult anterior sutures, which bite into muscular tissue of the patient's septum, passed through the fibrous aortic ring of the graft. Suturing was commenced by inserting three stay sutures through the aortic ring of the graft beneath the most dependent portion of each cusp (Fig. 4A). These sutures were passed into the left ventricular outflow region through corresponding points below the most dependent portions of each of the patient's excised cusps. The valve was then lowered into position and inverted down into the cavity of the left ventricle (Fig. 4B) so that the aortic ring presented as the most superficial part of the prosthesis; and the three sutures were tied. It was then a relatively simple matter to complete suturing the aortic ring of the graft to the host, using the three stay sutures. In case 39 this suture line was completed before it was realized that the graft had been turned inside out. The sutures had to be cut out and inserted again with the graft correctly placed ; but on this second occasion the suture line presumably passed too close to membranous ventricular septal edge for a permanent complete heart block resulted in this patient.

When the proximal suture line was completed the graft was pulled upwards into its correct position (Fig. 4C) and the uppermost points of each cusp attachment were sutured to the aortic wall just above the patient's cusp remnant. The upper sutures were then completed between these three points as continuous suture lines, picking up the aortic wall of the graft at the base of each cusp and, ideally, passing through the patient's cusp remnant. It was not always possible to use this remnant, because either the homograft valve tended to lie better a fraction higher than.this, or the line of the remnant was distorted or even bicuspid, or in calcified cases the valve had already been completely removed. In these cases the upper sutures were placed through the aortic wall above the cusp remnant usually at the lowest extension of each sinus of Valsalva, as shown in Fig. 4C; although, when a bicuspid valve had been excised (as was the 
case in 10 patients), the homograft valve required a completely new line of attachment dictated by the lie of its three cusps. With valve placement completed, the aortic incision was closed with a running suture started at each angle and carried anteriorly. Provided this single suture line was kept taut, it seldom leaked, and additional sutures were rarely required. The coronary cannulae were left in position until aortic closure was almost completed and the left heart was filled with blood.

The stage at which the heart was electrically defibrillated depended upon the excellence of the coronary perfusion. When both coronary arteries had been perfused, defibrillation was readily accomplished in every instance before removing the coronary cannulae and completing aortic closure, since by this stage the nasopharyngeal and myocardial temperatures had been returned to $35^{\circ} \mathrm{C}$. In these patients, once the heart was stable and blood was being ejected through the unclosed portion of the aortic incision, coronary perfusion was stopped, and the cannulae were removed after releasing the stay sutures around them. Aortic closure was then rapidly completed and the aortic cross-clamp was released. A large-bore hypodermic needle was passed through the front of the suture line to release any air trapped above the valve, and the left ventricular suction line was then removed. When, however, only the left coronary artery had been perfused, rewarming above $32^{\circ} \mathrm{C}$. was delayed until aortic closure was completed, and the aortic clamp was released with the heart still fibrillating. This allowed optimum coronary perfusion from the machine while rewarming was continued to about $34^{\circ} \mathrm{C}$. when defibrillation was attempted and was immediately successful in all but case 37 . In this patient, although five to 10 co-ordinated beats followed each attempt at defibrillation, ventricular fibrillation kept recurring over a period of 45 minutes. Fortunately, with the aid of various drugs, including procaine amide, electrical defibrillation was finally successful and a stable sinus rhythm was maintained thereafter.

Bypass was then stopped, adding blood from the machine until the venous pressure reached 12 to 15 $\mathrm{mm}$. Hg. After decannulation the pericardium was closed loosely over one soft rubber catheter, and a second catheter was placed in the anterior mediastinum.

In the six patients with multivalvular disease, while the homograft valve was inserted as described, a sternal-split chest incision was not satisfactory because it did not permit proper exposure of the mitral valve. Thus in case 39 , although the left atrium was widely opened from the right side, it was a rather small chamber and the mitral valve could not be exposed. A ruptured chorda, clearly seen from the aortic approach, could not therefore be repaired. In case 40 , a right lateral thoracotomy in the fifth intercostal space allowed easy cannulation of the coronary arteries through the usual transverse aortotomy and excellent exposure of the mitral valve, but suturing of the homograft aortic valve was extremely difficulto In cases 41,42 , and 43 , a bilateral anterior thoraco tomy was used and allowed good exposure of botkp valves. This incision is not favoured, however, in patients with advanced heart disease because of the greater blood loss and greater difficulty with ventilas tion post-operatively. In case 44 , a new incision was tried through the anterior half of the right fifth inter:costal space, across the sternum at this level and verti $\overrightarrow{\tilde{\omega}}$ cally upwards along the left sternal edge, inside the internal mammary vessels, where the second, third $\overrightarrow{\vec{x}}$ and fourth left costal cartilages were divided without opening the left pleura. This right antero-laterafo approach, with sternal division and the patient posi ${ }^{N}$ tioned slightly obliquely, gives surprisingly good exposure of aortic, mitral, and tricuspid valves without the disadvantages inherent in a bilateral anterion thoracotomy and is currently the approach of choicein multivalvular disease.

In all six patients the mitral valve was approacheक्ष from the right side and, when stenotic, was opened $P$ with a dilator and a knife. In case 44, because ofo valvular calcification and fibrosis, incompetence wasp produced, and a Starr-Edwards ball valve (1961) was therefore inserted in the mitral orifice. The tricuspido incompetence was corrected by a tricuspid annulo plasty. Of the three patients with mitral incompetence correction was not practicable, as already noted, in case 39 ; in case 42 , complete correction was achievedD by repairing a ruptured chorda in a manner described previously (Barratt-Boyes, 1963) and partially closingo the adjacent commissure; and in case 43, a StarrEdwards ball valve was inserted.

The duration of heart-lung bypass and of coronary. perfusion in each patient is listed in the Table. Case 10 required a three-hour bypass and coronary perfusione for 153 minutes, but an ascending arch aneurysmex was also resected in this patient. In most cases withoaortic incompetence alone, bypass time was just under two hours ; in cases with calcific stenosis it averaged slightly more than two hours ; and in the multivalvular? group a two-and-a-half- to three-hour perfusion was the rule. The serum haemoglobin level was measured spectrophotometrically at half-hourly intervals $D$ throughout the perfusion. The level in machine blood after perfusion was significantly raised in only four patients: to approximately $150 \mathrm{mg}$. in cases 3,4 , and 20 , and to $304 \mathrm{mg}$. in case 22 .

Post-operative management did not differ from that for other bypass cases. Venous and arterial pressures $\omega$ were monitored continuously for the first eight to 12 hours, and moderate elevation of the venous pres $\frac{0}{C}$ sure was maintained. Oxygen tents were seldom used, $\mathbb{\Phi}$ and intermittent positive pressure respiration was never ${ }^{+}$ required. Additional base was not given to any patient 0 as serial $p H$ and carbon dioxide values were satisfactory. Digitalis therapy was commenced or continued within 12 hours of warding. The administration of crystalline penicillin, one million units six-hourly, was continued for two weeks, and of streptomycin, 1 g. daily, for four days. Anticoagulants were not used. 
Intravenous mannitol was given in eight cases as a prophylactic measure against renal failure, and oliguria did not occur in these or in any other patient. In cases 4 and 22 the only indication for its use was a raised serum haemoglobin level above $100 \mathrm{mg}$. at the end of bypass (Porter, Sutherland, McCord, Starr, Griswold, and Kimsey, 1963), while in the remaining six there was evidence, already detailed, for preoperative renal damage.

\section{RESULTS}

Forty-one of the 44 patients survived operation with an apparently normally functioning homograft valve. One death occurred in each of the three groups.

Case 5 with aortic incompetence died within six hours of warding. In this patient, three pints of blood drained from the mediastinum during the first three hours, and there was a large haematoma beneath the right iliac fossa incision for insertion of the arterial cannula. The wounds were reopened and the bleeding points were controlled, but an hour or so later, when the blood pressure and other vital signs were satisfactory and bleeding had stopped, she suddenly vomited blood, inhaled a considerable quantity, and died soon after. Necropsy showed blood clot in the trachea and right main bronchus but no blood in the peripheral bronchi, and there was total collapse of the right upper lobe and partial lung collapse elsewhere. The stomach contained a small acute ulcer and blood, and it is assumed that this 'stress' ulcer was the source of the vomited blood. The homograft aortic valve was accurately placed and competent, and the other heart valves were normal.

Case 28, with calcific aortic stenosis, died on the third post-operative day from a large fullthickness infarction of the left ventricular wall due to compression of the left coronary artery and its two main branches by haemorrhage which lay outside the media. The mechanism of this bleeding is obscure as there was no medionecrosis of the wall or separation of the media, and the condition was therefore not a 'dissecting aneurysm'; nor could any communication be found between this blood and the vessel lumen.

Case 44, with aortic and tricuspid incompetence and mitral stenosis, died on the evening of the day of surgery. This patient had very severe disease with gross cardiomegaly (cardio-thoracic ratio $75 \%$ ). After replacement of the aortic and mitral valves and tricuspid annuloplasty the only valvular disease was slight tricuspid incompetence. His course was quite satisfactory with a normal blood pressure until 10 to 15 minutes before death when the direct recorder showed a rapid rise in venous pressure followed by ventricular fibrillation. Necropsy showed that the new valves were in an accurate position and the annuloplasty was intact ; it did not help to elucidate the cause of death.

Complications in the surviving patients are listed in the Table. Pulmonary embolism occurred three times and was treated successfully by several weeks' administration of anticoagulants. Two patients had a typical post-perfusion syndrome (Kreel, Zaroff, Canter, Krasna, and Baronofsky, 1960) and one a post-cardiotomy syndrome (Robinson and Brigden, 1963), and in case 43, who had bilateral anterior thoracotomies, a tracheostomy was required for pulmonary complications. Atrial fibrillation appeared post-operatively for the first time in about one-fifth of the patients but usually reverted spontaneously to sinus rhythm. One patient (case 20) developed ventricular tachycardia followed by ventricular fibrillation four days post-operatively. This responded to prompt external cardiac massage and defibrillation without any brain damage or other complication.

Significant post-operative morbidity occurred only twice. In the first patient (case 6), bacterial endocarditis developed, the temperature showing a progressive rise from the ninth to the twentieth day when a coagulase-negative Staphylococcus aureus was cultured from the blood. Fortunately this organism was fully sensitive to penicillin; treatment was recommenced and continued for four weeks in a dose of one million units fourhourly; sodium methicillin, $1 \mathrm{~g}$. four-hourly, was also given. The temperature fell quite quickly and there were no further positive blood cultures. During this period the patient had one attack of blindness in the right eye, lasting for about one minute, and subsequently had three similar episodes, the last occurring three months after operation but without any permanent visual field defect. As the temperature was then normal and blood cultures were consistently negative it was assumed that these were platelet emboli, and he was treated with anticoagulants for one month. An interval of seven months has now passed without further eye symptoms and it is nine months since antibiotics were stopped. The homograft valve continues to function normally and the patient is asymptomatic. One further patient (case 35 ) has had two momentary attacks of blindness which may be due to platelet emboli, for in this patient there has been no evidence of infection. The second patient with significant morbidity is case 39 who, in addition to uncorrected mitral incompetence, has a persistent surgically induced com- 


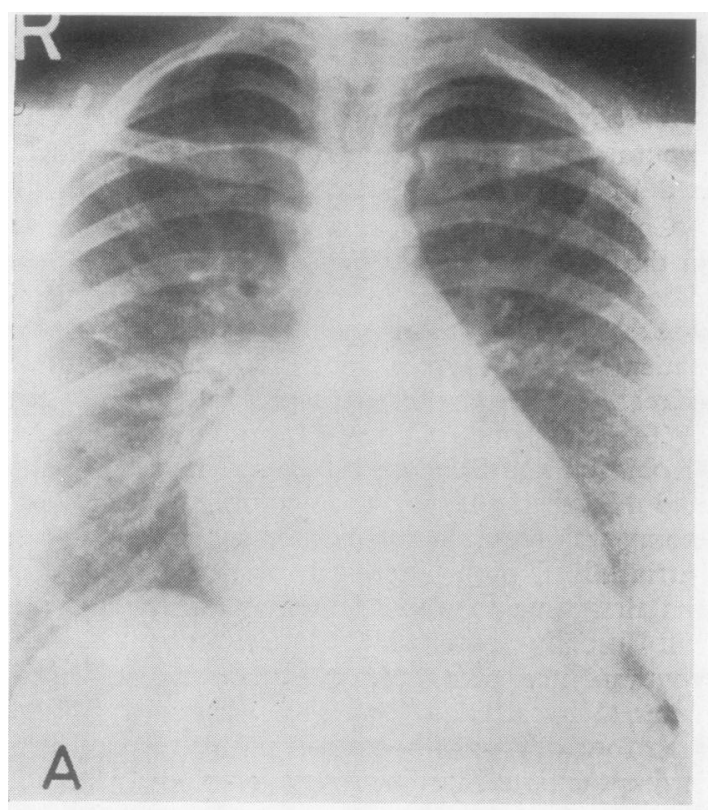

FIG. 5. Case 1. Postero-anterior radiographs of the chest

plete heart block, but despite these features his post-operative course has been smooth. An external cardiac pacemaker was used almost continuously in the early stages and was later replaced by an implanted unit. Three other patients (cases 29, 36 , and 42) had temporary heart block which was probably unrelated to the suturing of the valve.

The follow-up period is relatively short but is now 12 months or more for the first five patients (cases 1 to 4 and 22). The aortic valve homograft is functioning normally in all these patients, and cases $1,3,4$, and 22 are asymptomatic. The preoperative chest radiograph and electrocardiogram in case 1 may be compared with those taken approximately one year later (Figs. 5 and 6). At the time of operation this 14-year-old girl was in severe congestive heart failure from rapidly progressive aortic incompetence which followed bacterial endocarditis. One year later there was a faint ejection systolic murmur, a faint short early diastolic murmur, and normal splitting of the second heart sound; the chest radiograph and electrocardiogram were normal and the blood pressure was $105 / 70 \mathrm{~mm}$. Hg. These findings are representative of all the surviving patients with a sufficient period of follow-up except case 2. In these other patients the symptoms have rapidly lessened, and in the aortic incompetence group in particular the heart size has rapidly diminished. About half the patients have a faint short early diastolic murmur maximal along the left sternal edge. This

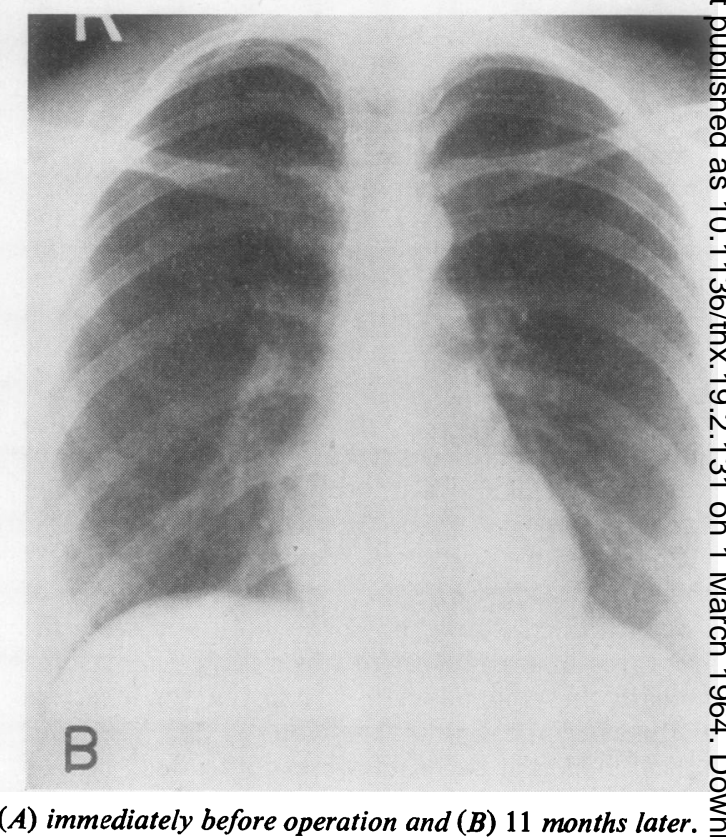

murmur has seldom been heard until about one week after operation and in some cases has sub 2 sequently tended to diminish in intensity. In no $\overrightarrow{\overrightarrow{0}}$ patient has there been any other clinical evidence 3 of residual aortic incompetence. An ejection systolic murmur of mild to moderate intensity has: invariably been present from the day of operation but has also tended to disappear. In case 23 this murmur was associated with a gradient of $36 \mathrm{~mm} . \times$ $\mathrm{Hg}$ across the homograft valve (Table). This patient had a rather small left ventricular outflow. and aortic ring, and the homograft valve was aO little large. Despite this, however, progress has been very favourable with complete loss of symp-음 toms of dyspnoea, angina, and syncope, and with $D$ a rapid return of the heart size and electrocardiogram towards normal (Fig. 7). Case 2N requires special mention because, although the aortic incompetence has been cured (B.P. 115/900 $\mathrm{mm} . \mathbf{H g}$ ), 10 months later there is still no reduc- $\omega$ tion in cardiomegaly or left ventricular hyper $\overline{2}$ trophy, and the patient has recently been admittedo to hospital because of recurrent congestive heart $\Phi$ failure. In the absence of evidence for residual $\stackrel{?}{+}$ valvular disease or active rheumatic fever, myo- $\frac{T}{0}$ cardial disease seems the probable cause of his $\frac{0}{\mathbb{D}}$ disappointing progress.

There have been two unexpected deaths about $\stackrel{\vec{\Phi}}{2}$ four months after operation. Case 7, a 62-year-old woman, had a history of severe angina decubitus, $ᄋ$ nocturnal dyspnoea, and orthopnoea. The aortico응 


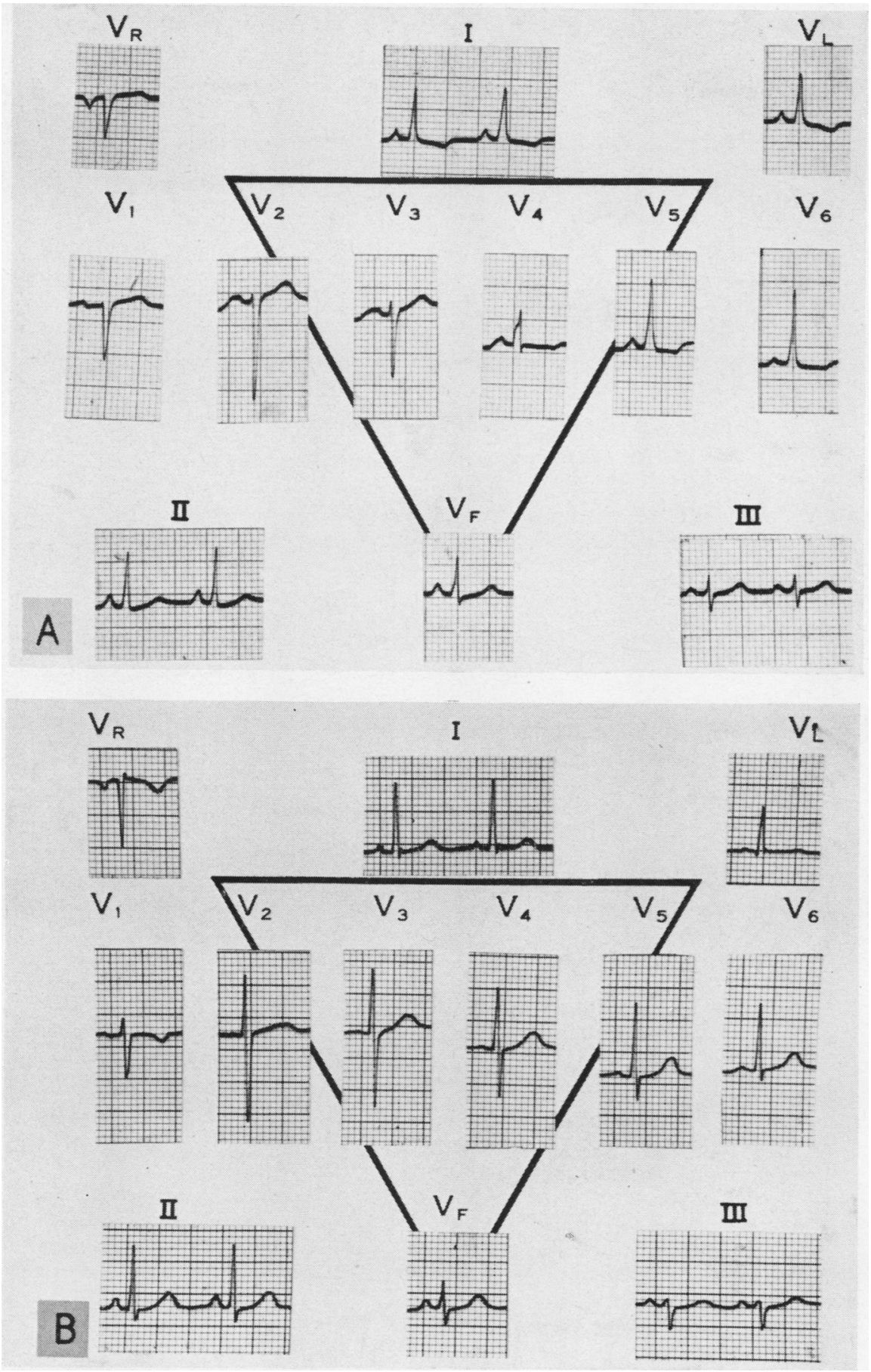

FIG. 6. Case 1. Electrocardiograms $(A)$ before surgery, patient receiving digitalis; (B) 11 months after operation. The $S T$ and $T$ changes, due to left ventricular hypertrophy and digitalis effect, have disappeared. 


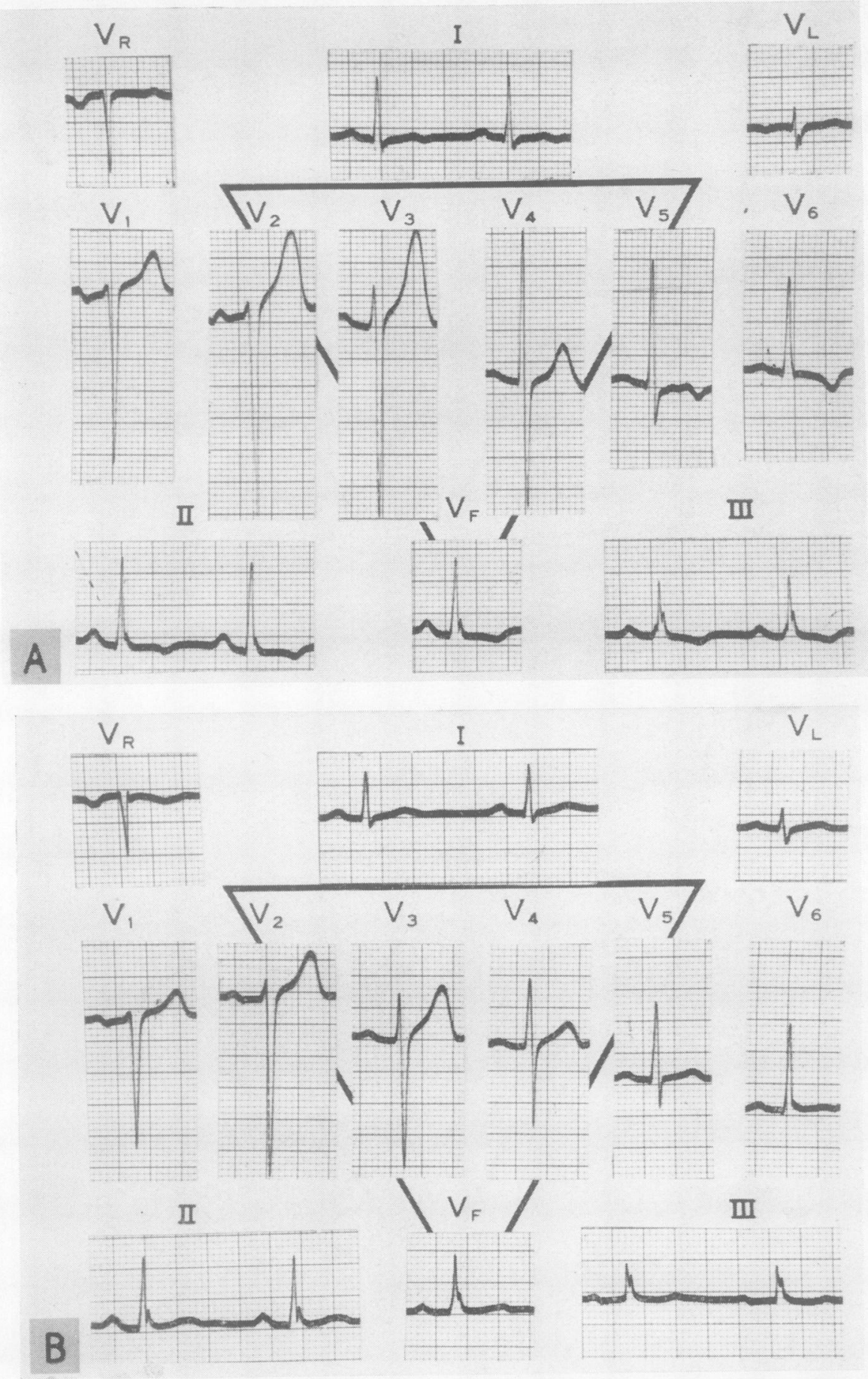

FIG. 7. Case 17. Electrocardiograms $(A)$ before surgery, patient not receiving digitalis; $(B)$ nine months after operation. The $S T$ and $T$ changes reflecting left ventricular hypertrophy have lessened considerably, although the voltage of $T$ in $V 6$ and $V_{F}$ has not yet returned to normal. 

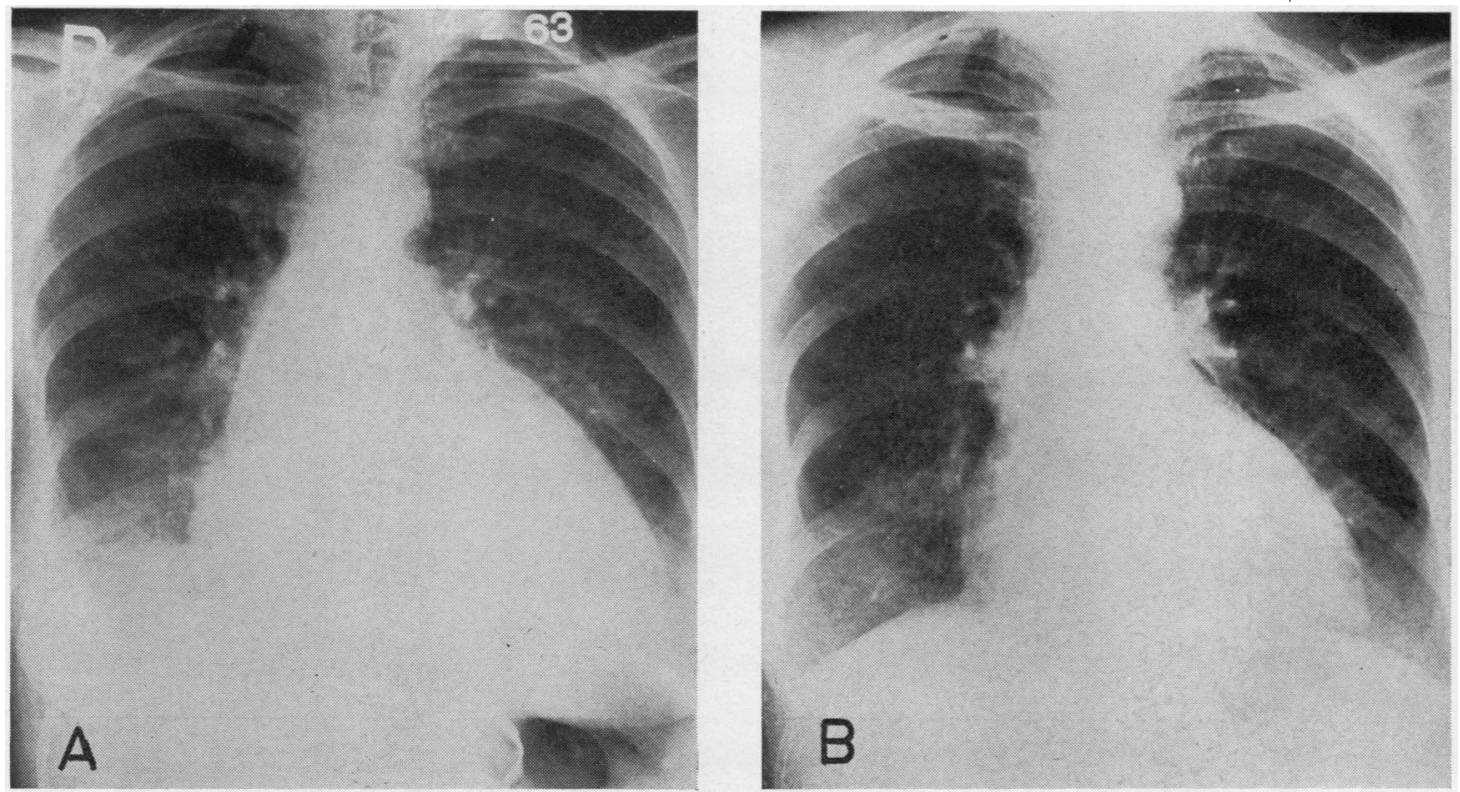

FIG. 8. Case 7. Postero-anterior radiographs of the chest $(A)$ two weeks before operation; note right basal pleural effusion; (B) three months later.



FIG. 9. Case 7. Myocardial mural artery showing eccentric fibro-elastic intimal thickening. Verhoeff elastic tissue stain plus Van Gieson $\times 125$. 


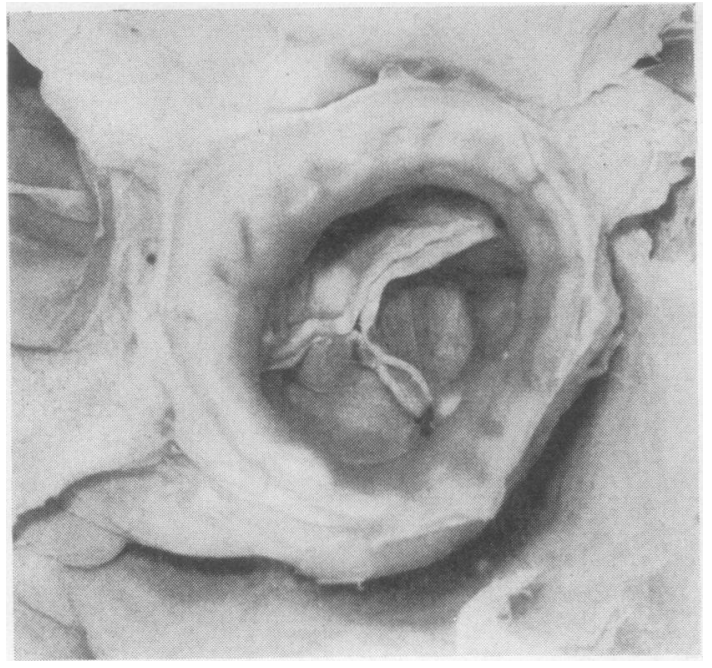

FIG. 10. Case 7. Homograft valve viewed from above. Aorta divided just above healed transverse aortotomy.

FIG. 11. Case 7. Sagittal sections through two of the cusps. $\frac{\bar{\sigma}}{\bar{\phi}}$ (A) Posterior cusp with host aortic wall above and anterior $\mathbb{\Omega}$ mitral leaflet $(M V)$ below. This portion of the graft is 0 rather bulky, partly because it contains muscular tissue $\rightarrow$ below the leaflet. Elastic tissue of the aortic portion of the $\vec{\circ}$ graft (ETG) lies inside host elastic tissue (ETH). A thick intimal sheath of young fibrous tissue (IFS) starts at the base of the cusp and extends over the upper suture line onto the aortic wall. A similar layer covers a calcific $\times$ nodule (arrow) presenting on the ventricular surface of the $\overrightarrow{0}$ thickened mitral leaflet. Verhoeff elastic tissue stain plus i van Gieson $\times 2$. (B) Anterior cusp. The graft is entirely $\vec{\omega}$ fibrous and less bulky at this point. The central defect separates graft from host and is lined by young fibrous 은 tissue. A silk suture is seen cut transversely near the lower edge of the graft. The intimal fibrous sheath above the cusp 3 is so thin here that it cannot be clearly seen. Haematoxylin and eosin $\times 2$.

FIG. 10 .

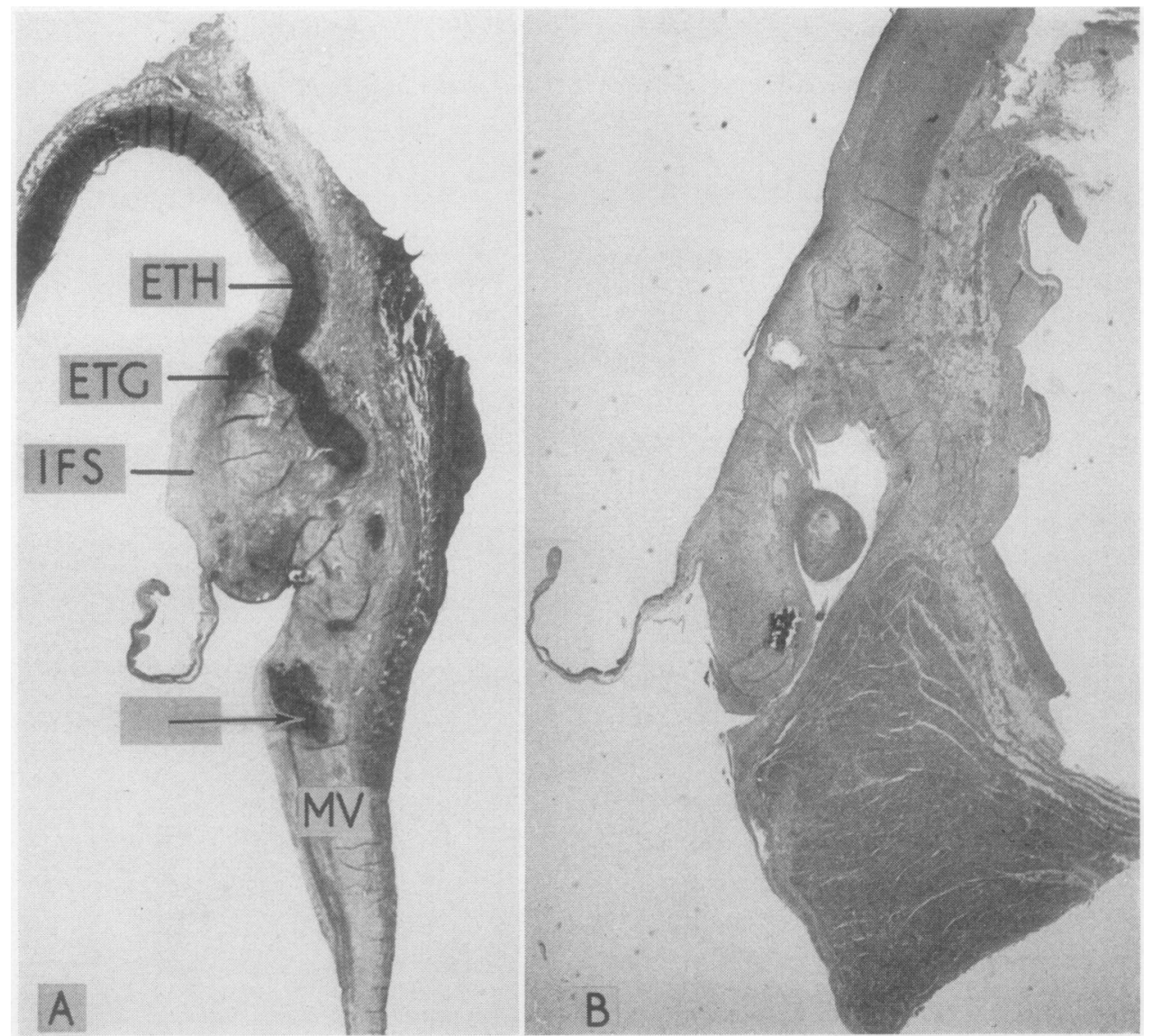

FIG. 11 . 


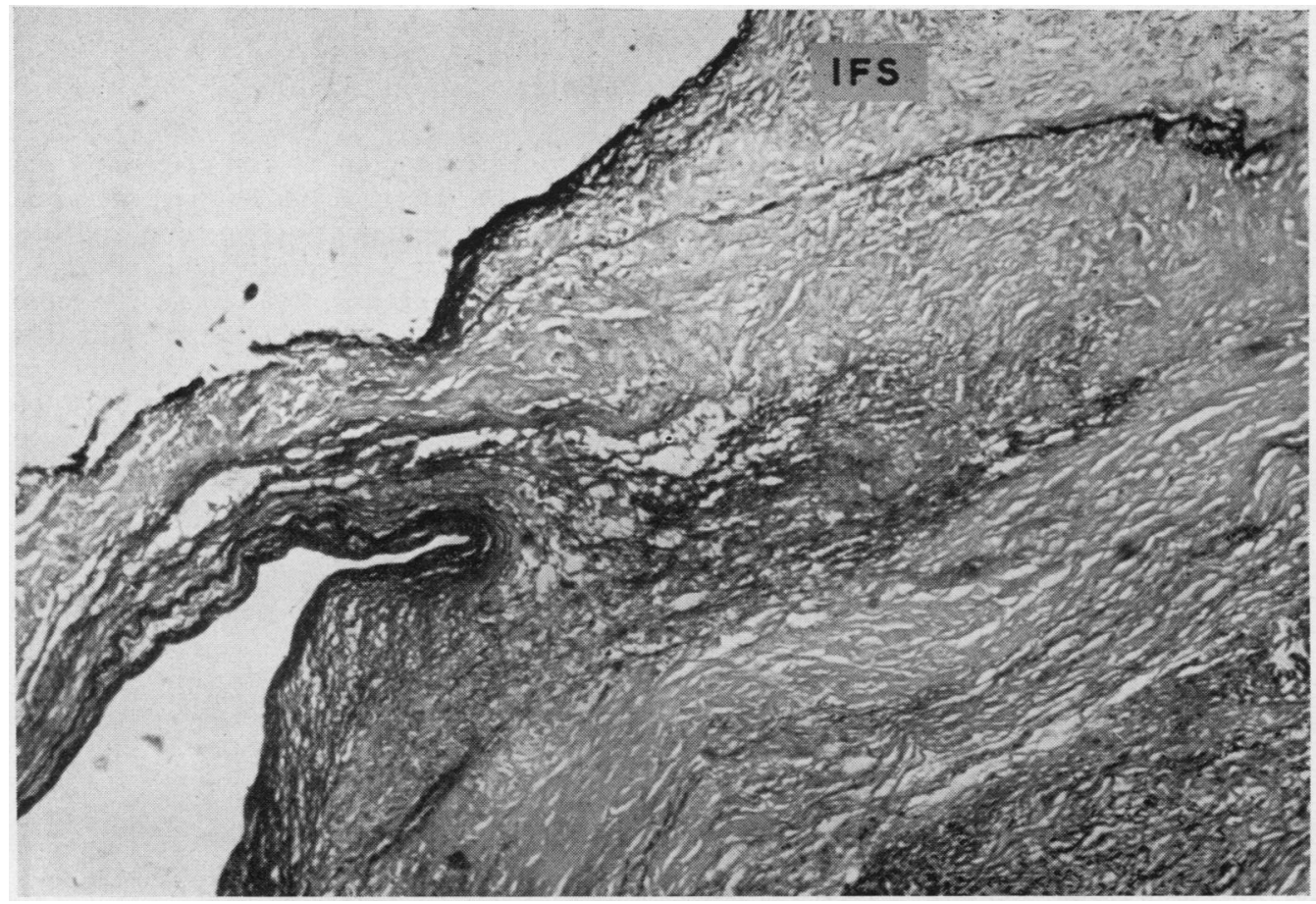

FIG. 12. Case 7. Base of homograft cusp and acellular aortic wall of graft at right. The intimal fibrous sheath (IFS) lies above the cusp and ends abruptly at its base. Verhoeff elastic tissue stain plus van Gieson $\times 45$.

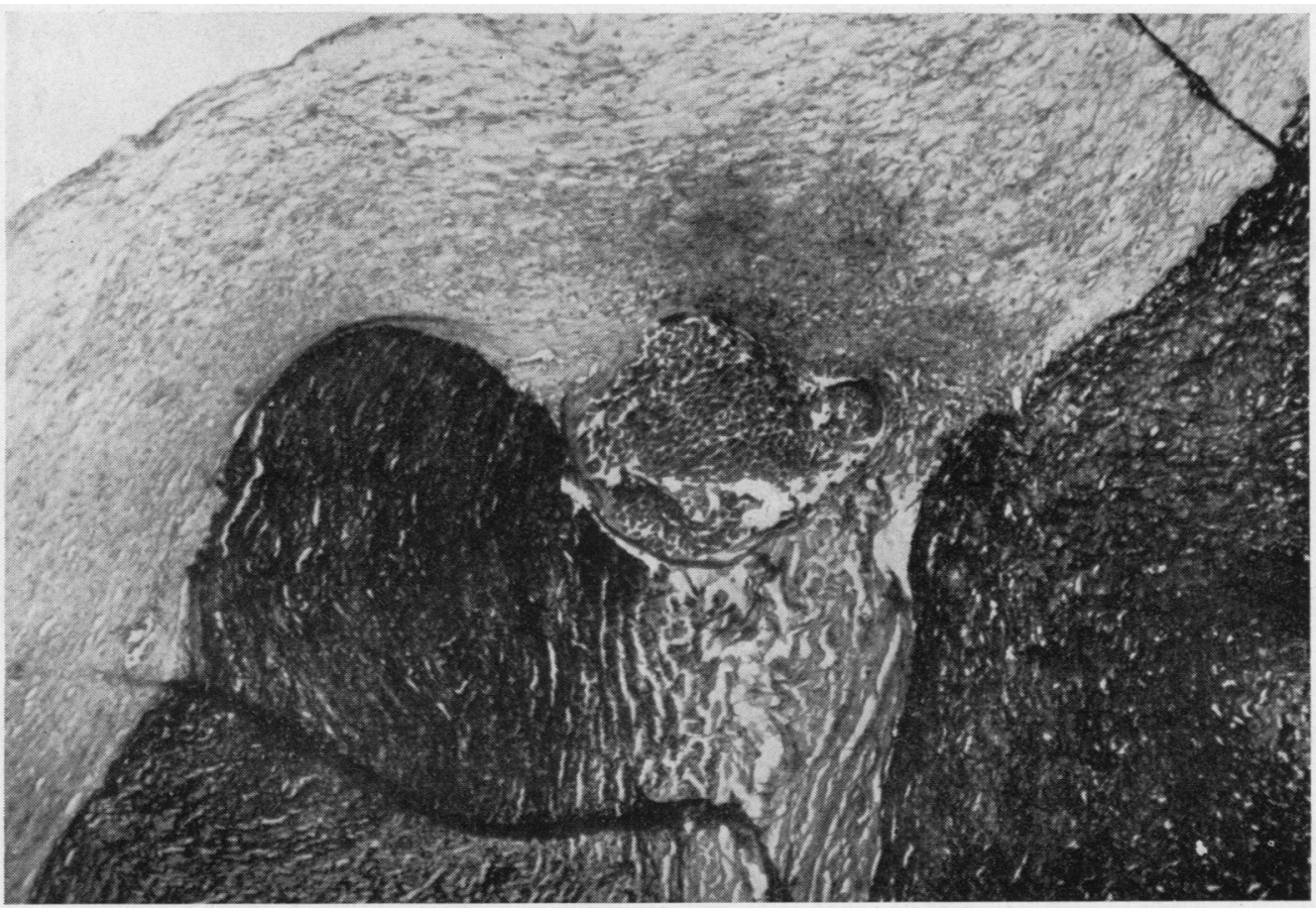

FIG. 13. Case 7. Upper suture line of graft under higher magnification. Black-staining host elastic tissue at right, well preserved graft elastic tissue at left, and transversely cut silk suture between. The young fibrous tissue of the intimal fibrous sheath lies above with the vessel lumen in the upper left corner. Cellular reaction, consisting of macrophages and less numerous lymphocytes and fibroblasts, is most marked around the suture material and is absent in the graft-host interface deep to the suture. Verhoeff elastic tissue stain plus van Gieson $\times 125$. 
valve was bicuspid, severely incompetent, and heavily calcified. Her post-operative course was uncomplicated, and when last examined three months after operation there had been a dramatic reduction in the heart size (Fig. 8) and she was symptom-free. The blood pressure was $135 / 85$ $\mathrm{mm}$. $\mathrm{Hg}$, and faint aortic systolic and diastolic murmurs were heard. Death occurred two weeks later and was immediately preceded by anginal pain which came on at rest. Necropsy showed death to be due to acute left ventricular failure with marked pulmonary congestion and oedema. The left ventricle showed residual hypertrophy and an old antero-lateral infarction. The coronary artery branches showed some atheromatous narrowing but were macroscopically patent. Microscopically, however, the majority of the small mural arteries were narrowed by eccentric

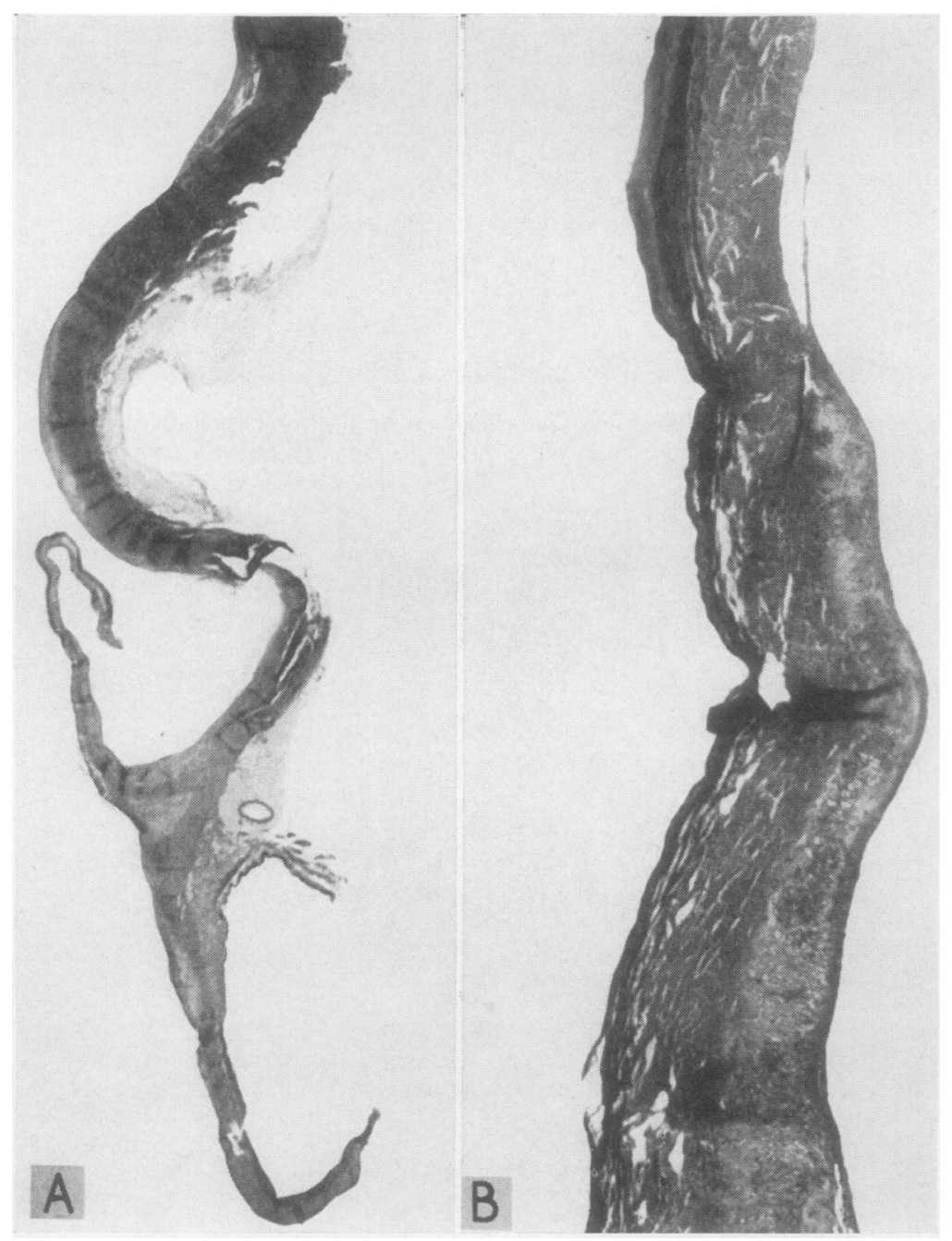

FIG. 14. Sagittal sections through the aortic valve of a 64-year-old woman. (A) Aortic wall lies above with elastic tissue tailing off well above the base of the aortic leaflet. Below is the anterior leaflet of the mitral valve. Verhoeff elastic tissue stain plus van Gieson $\times 2$. (B) Aortic cusp under higher magnification. In both photographs the ventricular aspect of the cusp with its major elastic tissue component lies to the left. The aortic aspect is predominantly collagenous. Verhoeff elastic tissue stain plus van Gieson $\times 45$. 


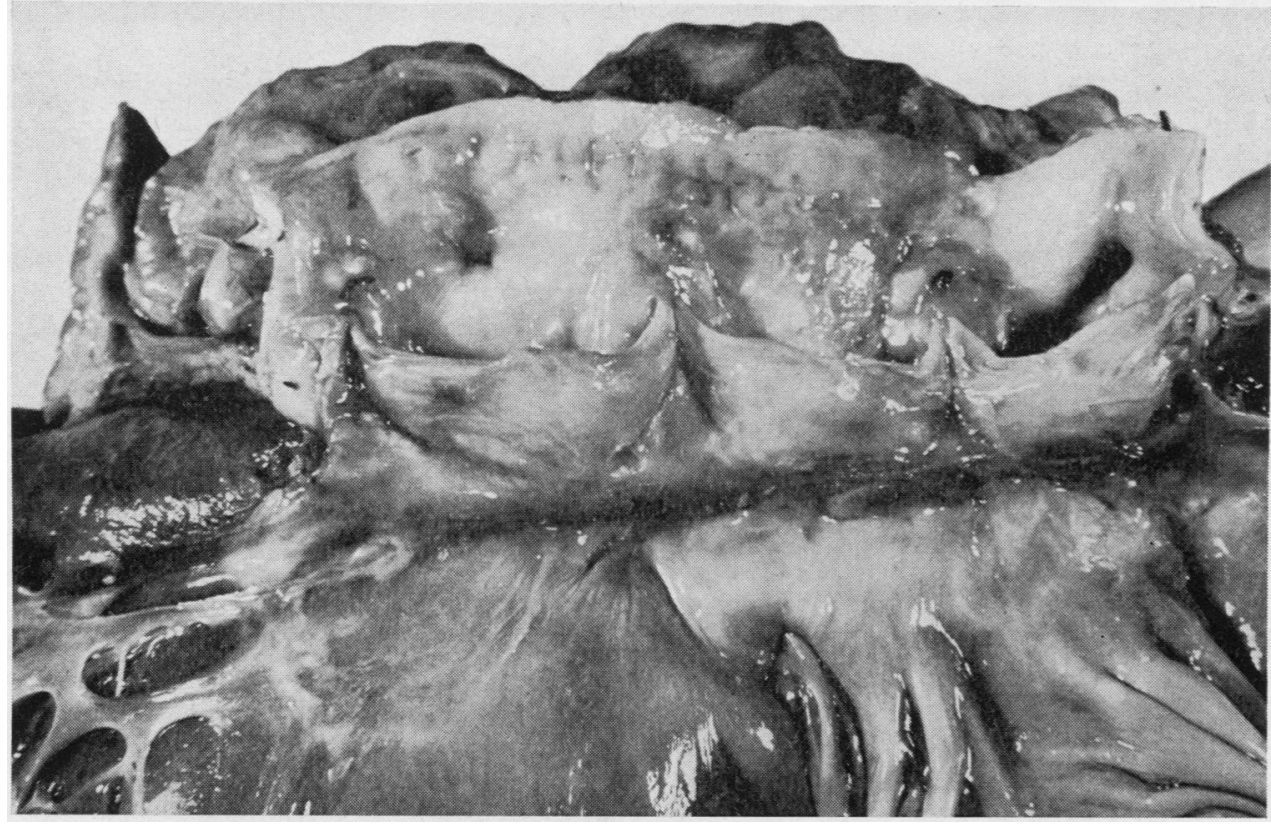

FIG. 15. Case 9. Homograft aortic valve laid open. The silk sutures above and below the graft and in the aortotomy above the graft are hidden and both coronary ostia are well seen. There are two small blind pockets beneath the lower suture line. The leaflets appear normal.
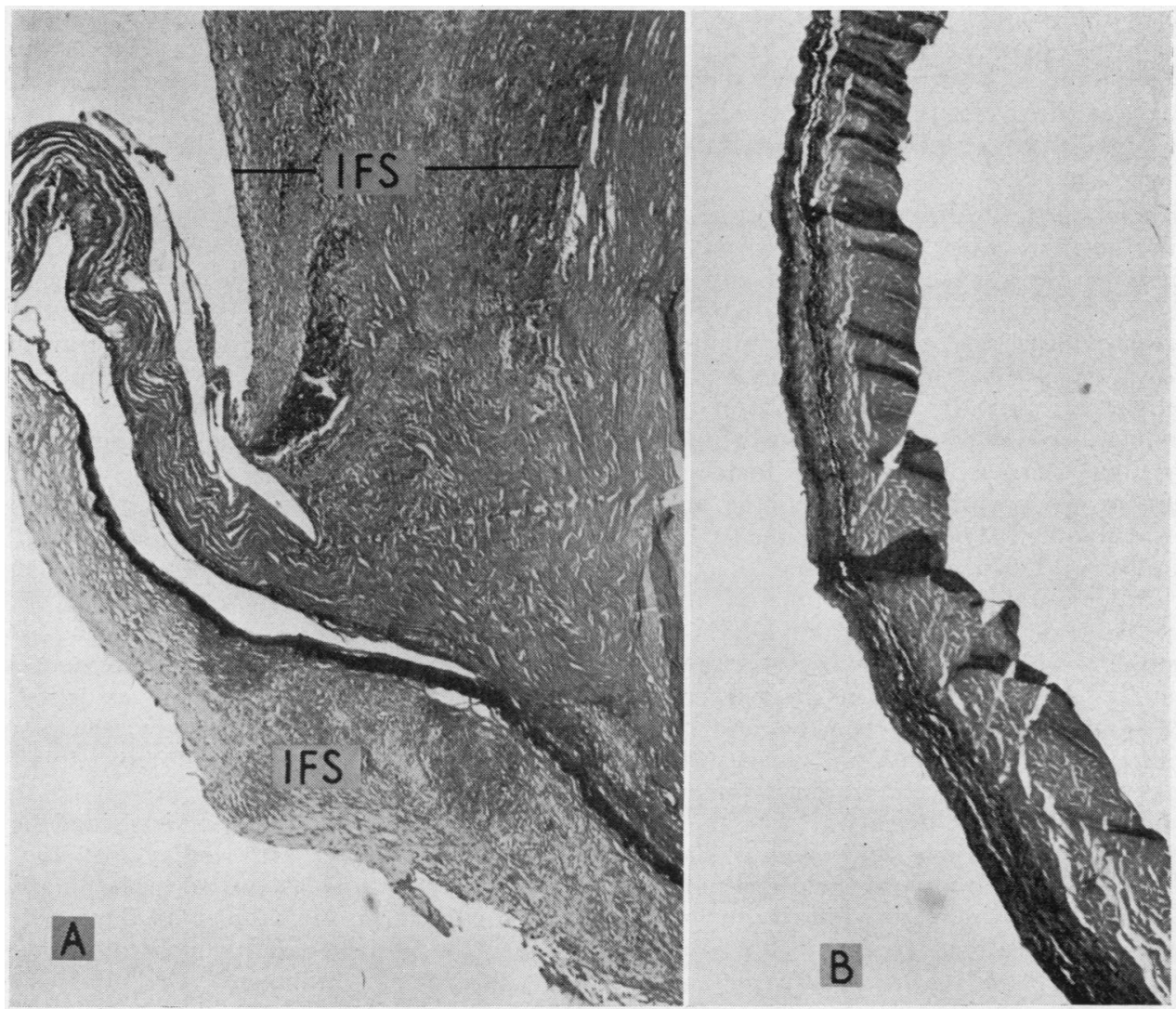

FIG. 16. Case 9. (A) There is extension of young intimal fibrous tissue (IFS) onto the ventricular aspect of this cusp. Splitting of the cusp is a processing artefact. Above the cusp the intimal fibrous sheath (IFS) is thick but does not extend on to the cusp. (B) Homograft leaflet showing normal architecture four and a half months after transplantation without any cellular reaction. Compare with Fig. 14. Verhoeff elastic tissue stain plus van Gieson $\times 45$. 
fibro-elastic intimal thickening (Fig. 9), similar to that seen in pulmonary vessels in low flow states and thrombo-embolic disease, and there were numerous irregular fibrous tissue scars of varying size scattered throughout the septum and left ventricle. Coronary insufficiency and death were presumed to result from these changes. The homograft valve could have been mistaken for normal as the silk suture lines were covered and smooth and the cusps were thin, semi-transparent, and pliable and easily approximated one another (Fig. 10). The microscopic features are illustrated in Figs. 11, 12, and 13. The aortic wall and ventricular muscle of the homograft had lost their cellular elements, but the elastic and collagen fibres were well preserved. Cellular reaction between graft and host was virtually confined to points around the sutures and to the intimal surface of the graft particularly above the cusps. Here there was a surprisingly thick sheath of young fibrous tissue which smoothed over the crevices of the upper suture line and became continuous above with host intima. Below, this new tissue stopped abruptly at the base of the cusps. The cusps were completely free of any reaction, and their architecture was indistinguishable from that of a normal valve from a patient of approximately the same age (Fig. 14).

The second late death was that of case 9, a 45year-old butcher, who developed aortic incompetence after an attack of bacterial endocarditis in 1952. Six years later angina appeared and then progressed until it came on after only minor effort. The aortic valve was tricuspid and severely calcified. Post-operatively he developed atrial fibrillation which converted spontaneously to sinus rhythm, but there were no other incidents. He returned to work within three months and was free of symptoms. When last examined the blood préssure was $135 / 85 \mathrm{~mm}$. $\mathrm{Hg}$, and there was a faint aortic ejection murmur but no diastolic murmur. He died suddenly four and a half months after surgery while shovelling gravel into a concrete mixer. As in the previous patient necropsy showed marked pulmonary oedema and residual left ventricular hypertrophy, and again, while all coronary arteries were macroscopically patent with unimportant atheroma, there was the same widespread fibro-elastic intimal thickening of the small mural arteries and numerous scattered areas of myocardial fibrosis, indicating diffuse coronary insufficiency. In the absence of any other explanation this is presumed to have been the cause of death. The homograft valve was obviously competent and looked normal (Figs. 15 and 16) except for two small blind pockets beneath the proximal suture line where the suture was either incomplete or had torn away over a distance of $3 \mathrm{~mm}$. In this patient the intimal sheath of young fibrous 0 tissue extended onto the under surface of one is cusp for a short distance (Fig. 16).

\section{DISCUSSION}

This series of 44 patients is too small and the $\vec{x}$ follow-up too short to permit firm conclusions, $\vec{\omega}$ but the results suggest that the homograft aortic i valve is a very satisfactory type of replacement $\vec{\omega}$ and they have encouraged us to continue with $\vec{\rho}$ this operation. Over a period of four and a half $\stackrel{\circ}{\triangle}$ months homograft valve leaflets have shown no $\vec{r}$ microscopic change in structure, and 15 months after insertion they continue on clinical grounds $\widehat{\widehat{C}}$ to function satisfactorily without evidence of any progressive change. These findings strongly support $\overrightarrow{\mathscr{Q}}$ the earlier beliefs of Gordon Murray (1956), which $\$$ are supported by the satisfactory six-year followup of his first patient in whom a homograft valve was inserted in the descending thoracic aorta (Kerwin et al., 1962). The absence of any microscopic evidence of rejection of the valve cusps in $\mathbb{D}$ our two patients leads to the hope that the elastic $\overrightarrow{\vec{A}}$ and collagenous tissue of the cusp, which is $\frac{9}{3}$ nourished entirely by the blood in contact with its surface, will function permanently.

Selection of patients for homograft valve replacement has differed a little in the various disease categories. In aortic incompetence this $\underset{\times}{\stackrel{0}{x}}$ operation was considered the treatment of choice $\bar{\sigma}$ after the first three advanced cases made uneventful recoveries, and in rheumatic and syphilitic cases $ᄋ$ no other form of valve replacement has since been used. Pending the results of further observation of $\mathrm{O}$ the long-term behaviour of these valves, however, surgery has to date been reserved for those with gross incompetence. In calcific aortic stenosis decalcification of the valve has as a routine been $\sigma$ tried first, and homograft replacement has been $N$ reserved for patients whose valves defied attempts $\mathbb{\omega}_{\mathrm{N}}$ at decalcification. While we now regard homograft 0 replacement as the method of choice in any patient whose valve cannot be decalcified, in the earlier $\frac{?}{\mathbb{D}}$ stages of the period under review single or multiple $\stackrel{\oplus}{+}$ cusp replacement with teflon leaflets (Bahnson 0 et al., 1960) was also used occasionally. In the multivalvular group surgery has been advised only when the patient was not controllable medically. $\overrightarrow{\mathbb{D}}$ It should be emphasized that in selecting the patients in this series none has been refused operation because of the severity of aortic valve disease, 
nor has a history suggestive of previous myocardial infarction been considered a contra-indication. Moreover, age alone has not been viewed unfavourably provided the patient was well preserved. The oldest patient in this series was 66 years, but in the same period two others, aged 68 and 71 years, have had their aortic stenosis relieved without the necessity for valve replacement, and all three of these patients have made very satisfactory progress.

The aseptic technique used to obtain valves in the mortuary within 15 hours of death has been exacting and time-consuming, and it is certainly easier when the pathologist collects the valve during the necropsy examination and has it sterilized by beta-propiolactone. While seven such valves have now been inserted in this series and have functioned well for up to three months, it seems preferable at this stage to obtain the valves sterile in case the sterilization process alters the host reaction to the graft. Once a sterile graft is obtained, freeze-drying has been accepted as the best method of long-term storage; but unfortunately it takes 30 minutes to reconstitute a freeze-dried valve and, if the principle is adopted of deciding to use a homograft only when decalcification has failed, this delay is unacceptable. If this practice is followed, one valve of 26 to $28 \mathrm{~mm}$. outside diameter, a size suitable for almost all adults, must always be kept stored in nutrient medium at $4^{\circ} \mathrm{C}$., so that it is immediately available when the decision to use a valve is made.

When inserting the valve, perfusion time and aortic cross-clamping may both be prolonged as the preliminary removal of a calcified valve takes time, and the suturing can be awkward because of the confined space. The perfusion technique used in these cases was designed to provide good operating conditions with an adequate flow and a minimum of haemolysis and has proved very satisfactory. Coronary artery perfusion is certainly mandatory and should be continuous in both coronary arteries. This requires cannulae that neither leak nor obstruct the field. The flexible plastic coronary artery lines of Mayo Clinic design with small self-inflating cuffed tips fulfil these criteria admirably, provided they are given additional stability by special retaining sutures which keep them in place throughout the suturing of the valve and until closure of the aortic incision is almost completed. Occasionally there was slight leakage around the left cannula tip but this was seldom severe enough to obscure the field. When both coronary arteries are continuously perfused without any leakage or other technical problems, it has not seemed necessary to lower the myo- cardial temperature below $30^{\circ} \mathrm{C}$. Moreover, this experience seems to indicate that when the right coronary artery is pathologically narrowed or even occluded adequate perfusion of the left coronary artery at a temperature of $27^{\circ} \mathrm{C}$. is usually sufficient to protect the myocardium for periods as long as 100 minutes. Complications arising from cannulation of the coronary arteries in the way described have been absent except in case 28 where death was the result of bleeding around the left coronary artery. Even in this patient, however, there is no clear proof that this was caused by the cannula as there was no tear in the vessel wall. In some of the earlier cases the heart was kept beating during insertion of the valve in the belief that coronary perfusion was more adequate than when ventricular fibrillation was present, but, since a contracting ventricle may increase the technical problem of suturing the valve, and since this group did no better post-operatively, this practice was abandoned.

The method used to suture the valve in position is based on the assumption that two suture lines are necessary for security. The proximal suture line below the cusps is not very difficult to insert once the graft is turned down into the ventricle : and it is an advantage that it is buried when the graft is pulled upwards into its correct final position. The additional segment of aortic wall and ventricular muscle which must be left attached to the graft below the cusps adds slight extra bulk and may be the cause of a minor gradient across the valve at the end of operation. This gradient has never proved significant, however, and as this portion of graft presumably atrophies once union is complete, it is of only temporary importance. This suture line lies just above the conduction bundle, which was permanently damaged in one patient. This error can be avoided by keeping the sutures away from the lower margin of the membranous interventricular septum. The second and distal suture line lies above the cusps and often passes partly or completely through the host aortic wall rather than the cusp remnant. Both proximal and distal suture lines are continuous stitching, as this avoids numerous knots and free silk ends, which are potential sites for infection, and also serves to distribute stresses evenly. This is particularly important when the valve removed is bicuspid, for then the upper suture line of the tricuspid prosthesis cannot follow the line of the excised cusps but ctosses the thin wall of the sinuses of Valsalva. Our experience makes. it quite clear that this is not dangerous, at least when using homograft valves, and that teflon pledgets outside the aortic wall are 
not necessary as there has never been leakage through the aortic wall and no graft has become detached.

The three hospital deaths in these 44 patients, two-thirds of whom had grade 4 symptoms and signs of very advanced disease, indicate that the risk of operation is small. Although about half the patients have a short faint aortic early diastolic murmur as well as an insignificant ejection systolic murmur, no patient appears to have significant aortic incompetence or stenosis on clinical grounds. In one patient a positive blood culture was obtained about three weeks after operation, and it seems that this infection, due to a penicillinsensitive Staph. aureus, has been completely eradicated by one four-week course of antibiotics. When it is realized that infection on a plastic aortic prosthesis is virtually incurable, this is a significant and most encouraging achievement.

The two deaths approximately four months after operation are disappointing, but neither can be attributed to aortic valve failure. In both patients death was probably due to coronary artery disease with widespread fibro-elastic intimal thickening in the smaller mural branches and secondary patchy fibrosis of hypertrophied myocardium. These lesions were an unexpected finding and their incidence and aetiology are being studied further.

\section{SUMMARY}

The aortic valve has been totally replaced by a homograft valve in 21 patients with incompetence, 17 with calcific stenosis, and six with multivalvular disease in which two or three valves were dealt with at the same operation. All the patients had severe valve lesions and 28 of the 44 patients had symptoms and signs of very advanced disease. Forty-one patients survived and have a normally functioning aortic valve up to 15 months later.

Two of the homograft valves have been examined at necropsy three and a half and four and a half months after insertion, and, in both, the architecture of the cusps was normal.

Significant morbidity has been confined to postoperative endocarditis, rapidly cured by a single course of antibiotics in one patient, and to permanent complete heart block in another.

The majority of the valves have been secured sterile and stored in nutrient medium or by freezedrying. Heart-lung bypass was conducted at $30^{\circ} \mathrm{C}$. with continuous perfusion of both coronary arteries using plastic coronary cannulae with selfsealing metal tips. The method of inserting the valve in a subcoronary position has been described in detail.
The results suggest that homograft aortic valve $\stackrel{\overrightarrow{5}}{\stackrel{5}{\circ}}$ replacement is the method of choice in the treat-들 ment of severe aortic incompetence and of most examples of severe calcific aortic stenosis.

My thanks are due to my cardiological colleague, $\stackrel{\mathbb{}}{\varrho}$ Dr. J. B. Lowe, for the medical management of these patients, and to Dr. Judith Smith for the pathology. $\vec{O}$

\section{REFERENCES}

Bahnson, H. T., Spencer, F. C., Busse, E. F. G., and Davis, F. W. Jr (1960). Cusp replacement and coronary artery perfusion in open operations on the aortic valve. Ann. Surg., 152, 494.

Barratt-Boyes, B. G. (1963). Surgical correction of mitral incom petence resulting from bacterial endocarditis. Brit. Heart $J \cdot \overrightarrow{0}$

, and Yarrow, S. (1961). A combined venous reservoir and defoaming chamber for use in a heart-lung by-pass circuit Aust. N.Z. J. Surg., 30, 260.

Beall, A. C. Jr., Morris, G. C. Jr., Cooley, D. A., and De Bakey,,

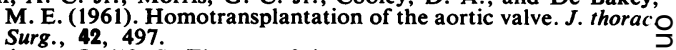

Brewin, E. G. (1956). The use of tissue transplants in the surgery of cardiac valvar disease-an experimental study. Guy's Hosp. Rep. 105, 328 .

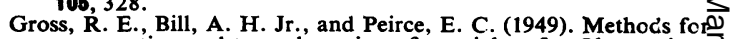
preservation and transplantation of arterial grafts. Observations on arterial grafts in dogs. Report of transplantation of preserved arterial grafts in 9 human cases. Surg. Gynec. Obstet., 88, 689-

Kerwin, A. J., Lenkei, S. C., and Wilson, D. R. (1962). Aortic-valveo homograft in the treatment of aortic insufficiency: Report of nine cases, with one followed for six years. New Engl. J. Med., 266, 852.

Kreel, I., Zaroff, L. I., Canter, J. W., Krasna, I., and Baronofsky I. D. (1960). A syndrome following total body perfusion. Surg Gynec. Obstet., 111, 317.

Lam, C. R., Aram, H. H., and Munnell, E. R. (1952). An experimenta study of aortic valve homografts. Ibid., 94, 129.

McGoon, D. C., Mankin, H. T., and Kirklin, J. W. (1963). Resultso of open-heart operation for acquired aortic valve disease. J.D thorac. Surg., 45, 47.

Murray, G. (1956). Homologous aortic-valve segment transplants as surgical treatment for aortic and mitral insufficiency. Angiology, 윽 7, 466.

Porter, G. A., Sutherland, D. W., McCord, C. W., Starr, A., Griswold, H. E., and Kimsey, J. (1963). Prevention of excess hemolysis during cardiopulmonary bypass by the use of mannitol. Circu=lation, 27,824

Rains, A. J. H., Crawford, N., Sharpe, S. H., Shrewsbury, J. F. D. and Barson, G. J. (1956). Management of an artery-graft bank with special reference to sterilisation by beta-propiolactone.
Lancet, 2, 830.

Robinson, J., and Brigden, W. (1963). Immunological studies in the post-cardiotomy syndrome. Brit. med. J., 2, 706.

Ross, D. N. (1962). Homograft replacement of the aortic valve 3 Lancet, 2, 487.

Starr, A., and Edwards, M. L. (1961). Mitral replacement : clinica experience with a ball-valve prosthesis. Ann. Surg., 154, 726.

\section{ADDENDUM}

Since this paper was submitted case 2 has died.D At necropsy the homograft aortic valve, which had으․ been inserted 14 months previously, looked similarN to the specimens obtained from cases 7 and 9. The cusps remained competent, pliable, and completely $N$ free of calcium, and clinically there was never any post-operative aortic diastolic murmur in this patient. Death was undoubtedly due to extensiveo myocardial fibrosis secondary to obliteration of the mural branches of the coronary arteries from? fibroelastic intimal thickening identical with that 0 described in cases 7 and 9.

A further 13 patients have now been operated $\stackrel{\mathbb{D}}{\circ}$ upon (four with aortic incompetence, eight with $\stackrel{\mathbb{Q}}{\Omega}$ calcific aortic stenosis, and one with multivalvularo disease), and one has died. 